\title{
Morphological Studies on the Influences of Hormones from Hypophysis-thyroid System on Langerhans' Islets of the Pancreas
}

\author{
By
}

\section{Michiko MASAKI}

The 1st Department of Medicine, Kyoto Pref. University of Medicine

(Director : Prof. H. Yoshida, M.D.)

Recently, the influences of the hormones from hypophysis-thyroid system on glucose metabolism has been studied. On the other hand, in the clinical observation, it has been frequently observed that diabetes mellitus or a simple symptom of urinary sugar is accompanied with hyperthyrodism. However, morphological influence of the hormones of this system on the pancreatic islets is not well known. In order to clarify the influence of the hormones of this system on the islets and to investigate the relationships between the histological findings and their functions, the author carried out the following series of experiments.

Materials and Methods

In this series of experiments, rats were used mainly, and sometimes rabbits were used.

The materials were colected under the conditions as described below.

These animals were divided into five groups as follows:

a) Thyradin (Powder of dried thyroid) administered group: Dosages were 20 $\mathrm{mg} / 100 \mathrm{~g} /$ day for rats and $200 \mathrm{mg} / \mathrm{head} /$ day for rabbits.

b) TSH administered group: Dosage for rats was $10 \mathrm{JSU} / 100 \mathrm{~g} /$ day.

c) Growth hormone administered group: Dosage was $10 \mathrm{mg}$ /head/day for rabbits.

d) Thyroidectomized group.

e) Hypophysectomized group.

In order to carry out the morphological studies and planimetric measurements of pancreatic islets on the above mentioned animals, the following methods were used:

a) Gomori's Chromealum-Hematoxylin-Phloxin and Aldehyde-Fuchsin dyingmethod, b) dying of zinc, c) dying of SS-SH groups, d) measurements of the area of Langerhans' islets, e) beta/alpha cell ratio, and f) nuclear volumes of alpha and beta cells.

Results

a) Thyradin administered group:

After the administration of $200 \mathrm{mg}$ each day for seven days, slight decrease in the Vol. 40 No. 7 
quantity of beta granula, margination of beta granula, decrease in the amount of zinc, and enlargement of nuclei were observed in Langerhans' islets. These results seemed to show that the release of insulin still exceeded its production, although the production was accelerated much more than that in normal state. Alph cells were not changed, apparently.

After the administration for thirty days, degenerative change of beta cells, remarkable decrease of beta granula, condensation of nuclei, decrease in the amount of zinc, and decrease in the amount of SS-SH groups were found. These findings support the suggestion that there is an exhaustion of beta cells after the course of hyperfunction.

For alpha cells, decrease of beta/alpha ratio and slight enlargement of the cells were observed.

In the case of rabbits which were administered thyradin for fifty two $\sim$ fifty six days, there was no difference in the findings from those in rats.

The hormones of the thyroid seemed to accelerate the function of Langerhans' islets and decelerate it later.

b) TSH administered group:

After the administration of TSH for seven days, decrease in the quantity of beta granula, decrease in the amount of zinc, decrease in the amount of SS-SH groups were observed. These results seemed to show the acceleration of the release of insulin. No enlargement of nuclei and nucleoli would show the absence of the acceleration in the production of insulin.

After the administration of TSH for thirty days, decrease in the quantity of beta granula and remarkable decrease in the amount of zinc seemed to show the acceleration of release of insulin. And also increase and decrease of SS-SH groups seemed to show the acceleration of biological production.

This acceleration of the function of beta cells seems to be a secondary effect of the influence of TSH on glucose metabolism through thyroid.

c) Growth hormone administered group:

After the administration of growth hormone of $10 \mathrm{mg} /$ day for fifty two $\sim$ fifty six days, decrease in the quantity of granula and zinc of beta cells, and the tendency to increase in the dimensions of Langerhans' islets were found. There was no change of nucleoli. Nuclei of alpha cells slightly enlarged.

These findings seemed to show only the accerelation of release of insulin, otherwise there was not any kind of change.

d) Thyroidectomized group :

Seven days after extraction, in Langerhans' islets contraction of beta cells, disappearance of polarity of granula, increase in the amount of zinc were observed, but there was no change of nuclei or nucleoli. These results support the suggestion that the reduction of release of insulin but no change in the biological production of insulin. 
Thirty days after the extraction, atrophy of beta cells, decrease in the amount of beta granula, zinc, and SS-SH groups, and contraction of nuclei were observed. Reduction of both release and biological production of insulin seemed to have occured. On the other hand, for alpha cells, decrease in nuclear volume seemed to show the reduction of the function of the cells.

In another word, it seemed to suggest that by the reduction of metabolism after thyroidectomy, the demand for insulin was reduced, and then, the function of beta cells remained stationary.

e) Hypophysectomized group :

Seven days after extraction, in both alpha and beta cells in Langerhans' islets, the contractions of cells and nuclei were found, and increase in the quantity of granula and decrease of SS-SH groups were observed in beta cells. From the results described already, reduction of the release of insulin and also the reduction of the biological production of insulin were suggested.

Fifteen days after the extraction, these changes became remarkable. In beta cells, atrophy of the cells and vacuolic degeneration were found. Decrease in the amount of zinc, the disappearance of polarity in zinc, and the condensation of nuclei were also found. These findings would suggest that, in beta cells, biological production of insulin was highly reduced.

In alpha cells, there was the same change as that in beta cells i.e., decrease in the amount of zinc and degeneration of cells, but the change was much less conspicuous.

(pp. 996 1016) 


\title{
下垂体甲状腺系の膵ラ氏島に及ぼす形態学的変化について
}

\author{
京都府立医科大学第一内科学教室（指導 吉田秀雄教授） \\ 正木 美 智子 \\ （昭和39年 4 月 10 日受付）
}

第 1 章
緒 言
第 2 章 実験材料
第 3 章 実験方法
第 4 章 実験成績
第 1 節 対照群
第 2 節 Hormone 剂投与群
I) Thyradin 投与群
II) Pretiron $(\mathrm{TSH})$ 投与群
目

\section{次}

III) Growth hormone (GH) 投与群 第 3 節 内分泌腺剔除群

I）甲状腺剔除群

II）下垂体剔除群

第 5 章 総 括

第 6 章 考 案

第 7 章 結 論

第 1 章 緒

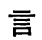

下垂体甲状腺系ホルモンがインシュリンに怙抗的に作用する一面を有するととは，1930年代より知られて いる事実である。 下垂体前葉ホルモンに糖尿病発症作用の存するてとは Houssay 一派 ${ }^{1 \sim 3}$ によつて最初に唱 導され，その中成長ホルモンが最も強い diabetogenic activity を有するてとは多くの人々によつて認められ

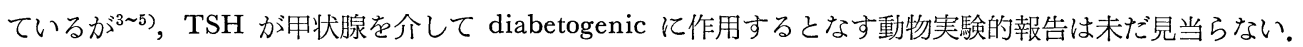
それにも拘らず吾々が臨床上屡々遭遇するように甲状腺機能九進症では明らかに高い頻度で尿糖が陽性に出 る。 Lahey ${ }^{6)}$ によると，500例の甲状腺疾患中尿糖を証明したものは，primary hyperthyroidism $38.6 \%$ ， adenomatous goiter with secondary hyperthyroidism $27.7 \%$, nontoxic goiter 14.8\% であつたと云う. 又との場合, 前者を治療するてとによつて後者も減少乃至治癒するてとは, 甲状腺ホルモンが糖代謝に対し て強く影響するてとを物語つている，てのように甲状腺ホルモンと糖代謝の関連は可成り緊密なるのがある が, 之等ホルモンは膵ラ氏島に対して如何なる作用をもつであろうか. 又その作用による変化は之らホルモ ンの一次的作用か，二次的な作用か等関する吾々の智識は極めて乏しい現状にある.

一方脺ラ氏島の形態学は Gomori の CHP 染色の発見以来急速な進歩を示し, 殊に近来は電子顕微鏡に よる観察 ${ }^{710)}$ 加えて大币な知見の進展がみられている. 然し乍ら形態と機能との相関は必ずしも常に平行 するとは限らず猶幾多の問題点を残している．教室では從来より各種内分泌腺と糖代謝との関係殊に蕂内分 泌との関係について検討しつつあるので，その研究の一環として私は下垂体甲状腺系ホルモンの膡内分泌に 及ばす影響について，主として形態学的にてれを把握せんとして次の実験を企てた。

\section{第 2 章 実 験 材 料}

下垂体甲状腺系の膆内分泌に及ぼす影響については主としてラットを使用し，てれによつて得た成績につ いて更に検討を加えるため, 次いで家鬼を使用し実験を行なつた。飼育法はラットは恒温室内で飼育し, 飼 料としてはオリエンタル固型飼料と水道水を与えた。家鬼は野菜を混入したおからで飼育した。

(I) ラット

体重100〜150gの Wister 系雄性ラットを次の群に分け各群夫々 5 匹宛とした.

1）対照群：正常ラットを固型飼料にて数日間飼育し，12時間絶食後屠殺し，直ちに膵臟を採取した。 


\section{2) Hormone 剂投与群}

a) Thyradin 投与群 : 甲状腺製剂 Thyradin (帝国臓器製) を体重 $100 \mathrm{~g}$ 当り $20 \mathrm{mg}$ を 7 日間及び 30 日間毎日 1 回筋注し, 絶食後屠殺した。

b) TSH 投与群 : 下垂体性 TSH 製剂 Pretiron (Schering 製) を使用し，1 日 1 回10 JSU/100 g 7 日間 及び30日間筋注後, 絶食屠殺した.

\section{3) 内分泌腺剔除群}

\section{a) 甲状腺剔除群}

私共の研究室で考案した方法により甲状腺を可及的完全に剔出した，尚屠殺時甲状腺を再検し手術の不完 全と思われるもの，術後体力消耗の著明なものは実験より除外することにした。

i ) 甲状腺剔除後短期生存群 : 甲状腺剔除後 7 日間生存せしめ，絶食後屠殺.

i i）甲状腺剔除後長期生存群 : 甲状腺剔除後30日間生存せしめ，絶食後屠殺.

b）下垂体剔除群

小山氏法変法による田中氏法により下垂体摘出を行なつた，術後は恒温保育器にて飼育し飲料水として 1 \%食塩水をあたえ, 術後 7 日及び15日で屠殺，材料を採取した。

\section{〔II〕家 鬼}

体重 $2 \mathrm{~kg}$ 前後の雄性家鬼15匹を次の如き 3 群に分け各群夫々 5 匹宛とした.

\section{1) 対照群}

2) Thyradin 長期投与群 : 甲状腺製剂 Thyradin 1 日 200mg/head 52～56日間継続投与し，絶食後屠殺.

3) Growth hormone 長期投与群：growth hormone (Armour) 1 日 10mg/head 52〜56 日間筋注投与後 屠殺.

\section{第 3 章 実 験 方 法}

ラットは撲殺, 家鬼は耳静脈より空気栓塞により屠殺後直ちに開復して膵臓を取出し, 膵体部及び尾部よ り材料を採取し所定の固定液に投入固定した. 染色法としては次のものを用いた。

1) Gomori 氏 Ghromealum-hematoxylin-phloxin 染色（以下 GHP 染色と略）

2) Gomori 氏 Aldehyde-fuchsin 染色 Masson 氏 Trichrom 変法

3) SS-SH 基染色（Barrnett \& Seligman 氏法)

本染色法は大要次の如くにして行なつた.

(1) Romeis 液で24時間固定後水洗24時間.

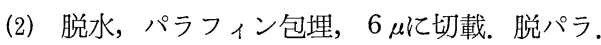

（3） $0.5 \mathrm{M}$ チオグリコール酸を $2 \% \mathrm{NaOH}$ で $\mathrm{pH} 8$ 亿調製した液に $37^{\circ} \mathrm{C} 2$ 時間 incubate する.

(4) 水洗 $\rightarrow 0.5 \%$ 醋酸液 $\rightarrow$ 水洗

(5) 切片を次の DDD $\left(2 \cdot 2^{\prime}\right.$-dihydroxy-6.6' dinaphthyl disulfide $)$ 液につけて $50^{\circ} \mathrm{C}$ で 1 時間放置. 次いで 10 分間室温放置冷却後溜水にて短時間水洗

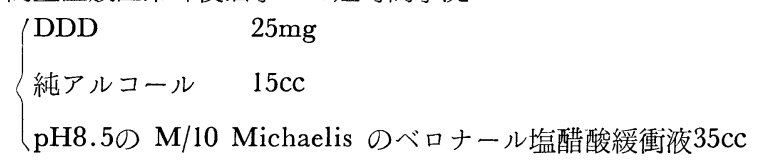

(6) $\mathrm{pH} 4.0 \sim 4.5$ の醋酸水にて 2 回洗滌.

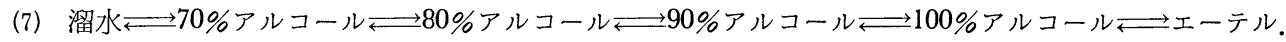

（8）切片を次の液中に室温で 2 分間浸漬後溜水にもどす.

$\{$ Naphthanil diazoblue B 50mg

$\{$ pH 7.4の M/10 Särensen 燐酸緩衝液 $50 \mathrm{cc}$

$$
\text { 第 } 40 \text { 巻 第 } 7 \text { 号 }
$$


(9) グリセリンゼラチン封入

\section{4) 重金属特に Zn の染色}

Timm のSulfid Silver Verfahren によつた，その操作は大要次の如くである。即ち型の如く切片を作成 し脱パラ後次の液を切片上に滴下し，光線を遮断して30分間放置する．次いで水洗し，脱水，透徹後鏡検す る.

染色液 : $20 \%$ アラビアゴム水溶液 $10 \mathrm{ml}$ 中に $1 \mathrm{M}$ 硝酸銀液 $0.1 \mathrm{ml}$ 及び水 $100 \mathrm{ml}$ に $2 \mathrm{~g}$ のハイドロキノン， $5 \mathrm{~g}$ のクエン酸をとかしたもの $2 \mathrm{ml}$ を加へよく振蕰する，用時調製。

5) ラ氏島の計測

a) ラ氏島面積測定：Gomori 氏 GHP 染色標本について Abbe の描画装置を用いて拡大描画し，Planimeter でその面積を測定し100 $\mu^{2}$ で表わした（顕微鏡倍率 $10 \times 10$ )。乙の方法により各群につき 3 例を選び 夫々 30 個計 90 個のラ氏島面積を計測した.

b) $\alpha \cdot \beta$ 細胞比の算定 : 各群につき 20 個のラ氏島を任意選択して夫々の $\alpha$ 細胞数 $\beta$ 細胞数を求め，その平 均値より各群の $\alpha \cdot \beta$ 細胞比を算定した.

c） $\alpha \cdot \beta$ 細胞核体積の測定 : 同上標本につき両細胞核を Abbe の描画装置により拡大描画し，その長径短 径を計測して, 細胞核を長軸を軸とした回転楕円体としてその体積を算定し， $\mu^{3} て ゙$ 表わした（顕微鏡倍率 $10 \times 100)$ ．乙の方法により各群につき 3 例を選び夫々 90 個の $\alpha$ 細胞核及び $\beta$ 細胞核の体積を計測した.

\section{第 4 章 実 験 成 績}

\section{第 1 節 対照群}

\section{1) CHP 染色による膵ラ氏島所見}

ラットの膵ラ氏島の CHP 染色による所見は, ラ氏島は小葉内に散在性に出現し外分泌実質部の内に封 ビこまれており，不完全な結合組織性被膜によつて囲まれている，島の周辺部は $\alpha$ 細胞帯が $\beta$ 細胞を取り囲 むが如く存在する，比較的大きなラ氏島では $\alpha$ 細胞が島内部に進入している像が見られる， $\alpha$ 細胞带による 外套部は境界不明膫な $\alpha$ 細胞の集団で，核力滵集して見える。原形質は一様に強い染色性を示し，phloxine 好性で濔漫性に赤染して見える。島の中心部は $\beta$ 細胞が主要成分をなし，そてには毛細血管，類洞腔が豊富 に存在する。 $\beta$ 細胞は多角形乃至不正形で, 隣接細胞との境界が比較的不鮮明である.その原形質には hematoxylin 好性の桿状体又は顆䊉が豊富に存在する，全体としては明調で強い染色性を示さないが，顆䊀が充 満しているものは黒青色にそまつて見える.ラットでは $\alpha$ 細胞と $\beta$ 細胞の核についてはそれ程判然とした区 別は認められなかつた，又 $\delta$ 細胞の存在については吾々の CHP 染色では確認出来なかつた。

正常家鬼における5氏島の GHP 染色所見は，ラ氏島は大小が不同で小葉中心部には比較的大きなラ氏島 が存在する一方，周辺部では極めて小さなものも見られる。家鬼ではラットのそれと稍々異なり， $\alpha$ 細胞は 外套を作らず島周辺部に小塊をなして散在する一方, 島中心部にも散見される。従つてその数はラットに比 して少ない，又家鬼の $\alpha$ 細胞は境界が可成り明膫で原形質は phloxine に強い染色性を有し普通は瀰漫性に 染まるが，時として染色性が不均等で核の一側に不染性の像を認める場合も見られる。 概祆明膫であり，ラ氏島の中央部に索状配列をなして存在する。CHP 染色ではCH好性の顆粒が充満してい るが，その浱度は一般に類洞腔側に強く認められ，必ずしも均一でない， $\alpha \cdot \beta$ 細胞核はあまり差を認めない が， $\alpha$ 細胞核は染色質にやや乏しく一般に明調である。 ラ氏島被膜は完全でなく所々に切目がみられる。

\section{2) Aldehyde fuchsin (AF) 染色によるラ氏島所見}

正常ラットラ氏島における $\mathrm{AF}$ 染色所見は，CHP 染色と同様にラ氏島の周辺は橙色に染つた $\alpha$ 細胞が $\beta$ 細胞芭取囲み外套部を形成している。 $\alpha$ 細胞は境界不明膫でその原形質には橙色の微細な顆粒状物質か均等 灀漫性に搪がり胞体は橙色飞染め出される。 $\beta$ 細胞原形質は aldehyde fuchsin によつて深紫色に染め出さ れる微細な顆粒が豊富に存在するのが認められ，細胞質内に顆粒が充満している時は全体が深紫色に染まつ てみえる. 
正常家鬼の aldehyde fuchsin 染色では, 前述の GHP 染色の所見と本質的には何ら異なるものではない が，本染色では $\beta$ 顆粒の類洞腔に面して偏在する傾向が一首強く認められる。

\section{3) SS-SH 基染色によるラ氏島所見}

ラット及び鬼の愺藏における SS-SH 基物質は Bcrrnett \& Seligmon の反応により赤紫色に染められる. 外 分泌部の腺細胞ではての反応が強くみられ，SS-SH 基物質は濃い赤紫色に染色される. 特に細胞基底部及び 膵管上皮に強い反応を示すが，ラ氏島では一般に該反応による染色性は比較的弱い．然し詳細に之を観察す れば $\beta$ 細胞は $\alpha$ 細胞に比べて濃く染め出されていて，明らかに両者は区別が可能である.

\section{4) 亜鉊染色によるラ氏島所見}

私の用いた亜鉛染色法はF・Timm(1958)による重金属に対するSulfid Silver Verfahren で之を芼ラ氏島に 応用した．その所見はラットでは好銀性顆粒はラ氏島 $\beta$ 細胞に於て微細な顆粒として原形質内に認められる が，核の周辺部には比較的疎で原形質辺縁部殊に sinusoid に面して密集して存在する傾向がある， $\alpha$ 細胞 には $\beta$ 細胞より一層高い密度の顆粒として存在し時として核を除く胞体全域に亘つて黒色の沈着物として認 められる。

家鬼では好銀性顆粒は $\beta$ 細胞にのみ認められ， $\alpha$ 細胞には殆んど全く認められないのが特徴的である， $\beta$ 細胞では細胞核周辺部では疎に存在するが辺縁部に於ては sinusoid に面して濃密な顆粒状物質として認め られるととはラットの場合とその軌を一にする。

ラ氏島に於ける亜鉛の存在に関しては多くの説がなされているが，動物の種族によつて刺鉛の量に差異が みられることは一致した意見である. 又 $\beta$ 細胞に於ける亜鉛の存在は Insulin の存在形式と密接に関係する と考光られるが，ラットの如く $\alpha$ 細胞にみられる亜鉛は矢張り糖代謝に関係はするが， $\alpha$ 顆粒とは一応別の ものと考えられている.

\section{5) ラ氏島計測}

a) ラ氏島面積：健常ラット 3 匹について90個のラ氏島の平均面積はTable 1 の如く $101.4 \pm 14.6 \times 100 \mu^{2}$ を示している．正常家鬼のラ氏島はラットに比して大小様々であるが， 3 匹計 90 個のラ氏島の平均面積は

Table 1. Dimensions of islets of Langerhans, and nuclear volumes of the $\alpha$ and $\beta$ cells in Langerhans' islets of rats pancreas

\begin{tabular}{|c|c|c|c|c|}
\hline & $\begin{array}{l}\text { Rat } \\
\text { No. }\end{array}$ & $\begin{array}{l}\text { Dimension of the } \\
\text { Islet of Langerhans }\end{array}$ & $\begin{array}{l}\text { Nuclear volume } \\
\text { of } \alpha \text {-cell }\end{array}$ & $\begin{array}{c}\text { Nuclear volume } \\
\text { of } \beta \text {-cell }\end{array}$ \\
\hline Normal & $\begin{array}{r}\text { No. } 1 \\
\text { No. } 2 \\
\text { No. } 5 \\
\text { average }\end{array}$ & $\begin{array}{l}88.0 \times 100 \mu^{2} \\
111.4 \\
104.9 \\
101.4 \pm 14.6\end{array}$ & $\begin{array}{l}66.8 \mu^{3} \\
67.0 \\
79.3 \\
70.0 \pm 1.9\end{array}$ & $\begin{array}{l}71.4 \mu^{3} \\
76.9 \\
76.7 \\
75.0 \pm 2.0\end{array}$ \\
\hline $\begin{array}{c}\text { Thyradin } \\
7 \text { days }\end{array}$ & $\begin{array}{r}\text { No. } 7 \\
\text { No. } 8 \\
\text { No. } 10 \\
\text { average }\end{array}$ & $\begin{array}{l}87.1 \\
98.0 \\
108.5 \\
98.2 \pm 11.5\end{array}$ & $\begin{array}{l}61.7 \\
58.0 \\
76.2 \\
64.5 \pm 3.7\end{array}$ & $\begin{array}{l}81.5 \\
76.7 \\
69.9 \\
76.0 \pm 3.2\end{array}$ \\
\hline $\begin{array}{l}\text { Thyradin } \\
\text { 30days }\end{array}$ & $\begin{array}{r}\text { No. } 11 \\
\text { No. } 12 \\
\text { No. } 13 \\
\text { average }\end{array}$ & $\begin{array}{c}83.4 \\
69.2 \\
69.6 \\
74.7 \pm 13.1\end{array}$ & $\begin{array}{l}57.1 \\
63.6 \\
79.8 \\
66.8 \pm 2.8\end{array}$ & $\begin{array}{l}52.2 \\
55.0 \\
68.3 \\
58.5 \pm 2.7\end{array}$ \\
\hline $\begin{array}{l}\text { TSH } \\
7 \text { days }\end{array}$ & $\begin{array}{r}\text { No. } 17 \\
\text { No. } 19 \\
\text { No. } 20 \\
\text { average }\end{array}$ & $\begin{array}{l}105.7 \\
117.6 \\
99.6 \\
107.6 \pm 14.0\end{array}$ & $\begin{array}{l}63.2 \\
63.0 \\
66.8 \\
64.3 \pm 2.1\end{array}$ & $\begin{array}{l}75.9 \\
75.3 \\
73.0 \\
75.4 \pm 2.1\end{array}$ \\
\hline
\end{tabular}




\begin{tabular}{|c|c|c|c|c|}
\hline $\begin{array}{c}\text { TSH } \\
30 \text { days }\end{array}$ & $\begin{array}{r}\text { No. } 21 \\
\text { No. } 22 \\
\text { No. } 25 \\
\text { average }\end{array}$ & $\begin{array}{l}91.2 \\
99 \cdot 7 \\
109.5 \\
100.1 \pm 12.4\end{array}$ & $\begin{array}{l}68.8 \\
75 \cdot 4 \\
66.4 \\
70.2 \pm 3.2\end{array}$ & $\begin{array}{l}85.8 \\
81.5 \\
74.1 \\
80.4 \pm 2.4\end{array}$ \\
\hline $\begin{array}{l}7 \text { days after } \\
\text { thyroidectomy }\end{array}$ & $\begin{array}{r}\text { No. } 26 \\
\text { No. } 28 \\
\text { No. } 29 \\
\text { average }\end{array}$ & $\begin{array}{l}81.8 \\
121.7 \\
113.3 \\
105.2 \pm 18.2\end{array}$ & $\begin{array}{l}59.2 \\
72.7 \\
69.1 \\
68.8 \pm 2.1\end{array}$ & $\begin{array}{l}82.6 \\
77.0 \\
78.3 \\
79.3 \pm 2.9\end{array}$ \\
\hline $\begin{array}{l}\text { 30days after } \\
\text { thyroidectomy }\end{array}$ & $\begin{array}{r}\text { No. } 30 \\
\text { No. } 31 \\
\text { No. } 33 \\
\text { average }\end{array}$ & $\begin{array}{l}105.8 \\
91.9 \\
90.6 \\
96.8 \pm 9.7\end{array}$ & $\begin{array}{l}66.1 \\
57.6 \\
59.4 \\
61.0 \pm 2.0\end{array}$ & $\begin{array}{l}70.7 \\
69.2 \\
71.7 \\
70.5 \pm 3.1\end{array}$ \\
\hline $\begin{array}{l}7 \text { days after } \\
\text { Hypophysect. }\end{array}$ & $\begin{array}{r}\text { No. } 37 \\
\text { No. } 39 \\
\text { No. } 40 \\
\text { average }\end{array}$ & $\begin{array}{l}109.6 \\
103.9 \\
120.1 \\
101.0 \pm 10.0\end{array}$ & $\begin{array}{l}45.9 \\
51.3 \\
59.0 \\
52.1 \pm 1.6\end{array}$ & $\begin{array}{l}51.8 \\
61.7 \\
75.4 \\
63.2 \pm 2.2 \\
\end{array}$ \\
\hline $\begin{array}{l}15 \text { days after } \\
\text { Hypophysect. }\end{array}$ & $\begin{array}{r}\text { No. } 41 \\
\text { No. } 43 \\
\text { No. } 45 \\
\text { average }\end{array}$ & $\begin{array}{c}72.0 \\
83.0 \\
89.9 \\
81.6 \pm 15.4\end{array}$ & $\begin{array}{l}44.9 \\
63.6 \\
68.0 \\
58.8 \pm 2.7\end{array}$ & $\begin{array}{l}50.4 \\
56.4 \\
58.4 \\
55.1 \pm 1.5\end{array}$ \\
\hline
\end{tabular}

Table 2. Dimensions of islets of Langerhans, and nuclear volumes of the $\alpha$ and $\beta$ cells in Langerhans' islets of rabbits pancreas

\begin{tabular}{c|c|c|c|c}
\hline & $\begin{array}{c}\text { Rabbit } \\
\text { No. }\end{array}$ & $\begin{array}{c}\text { Dimension of } \\
\text { Islet of Langerhans }\end{array}$ & $\begin{array}{c}\text { Nuclear Volume } \\
\text { of } \alpha \text {-cell }\end{array}$ & $\begin{array}{c}\text { Nuclear Volume } \\
\text { of } \beta \text { cell }\end{array}$ \\
\hline \hline \multirow{5}{*}{ Normal } & No. 1 & $110.7 \times 100 \mu^{2}$ & $64.4 \mu^{3}$ & $65.0 \mu^{3}$ \\
& No. 2 & 138.3 & 67.8 & 70.3 \\
& No. 4 & 117.9 & 72.4 & 83.5 \\
& average & $122.3 \pm 14.3$ & $67.9 \pm 1.1$ & $72.9 \pm 2.0$ \\
\hline \multirow{5}{*}{ Thyradin } & No. 6 & 148.6 & 61.4 & 62.3 \\
& No. 8 & 149.6 & 76.0 & 70.4 \\
& No. 9 & 152.4 & 81.1 & 73.1 \\
& average & $150.2 \pm 15.3$ & $72.9 \pm 2.2$ & $68.6 \pm 2.6$ \\
\hline \multirow{5}{*}{ GH } & No.12 & 136.8 & 67.8 & 78.5 \\
$52 \sim 56$ days & No. 14 & 115.2 & 74.4 & 69.3 \\
& No.15 & 147.6 & 79.8 & 63.1 \\
& average & $131.8 \pm 13.6$ & $75.5 \pm 1.8$ & $70.6 \pm 3.2$ \\
\hline
\end{tabular}

Table 2 そ示す如く $122.3 \pm 14.3 \times 100 \mu^{2}$ となりラットのそれに比し大である.

b) $\alpha \cdot \beta$ 細胞比 : 各群につき20個のラ氏島においてラットでは $\alpha$ 細胞数の平均值は $29.5, \beta$ 細胞数の平均

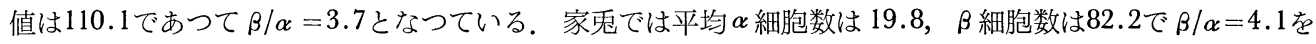
示している. (Table 3) 


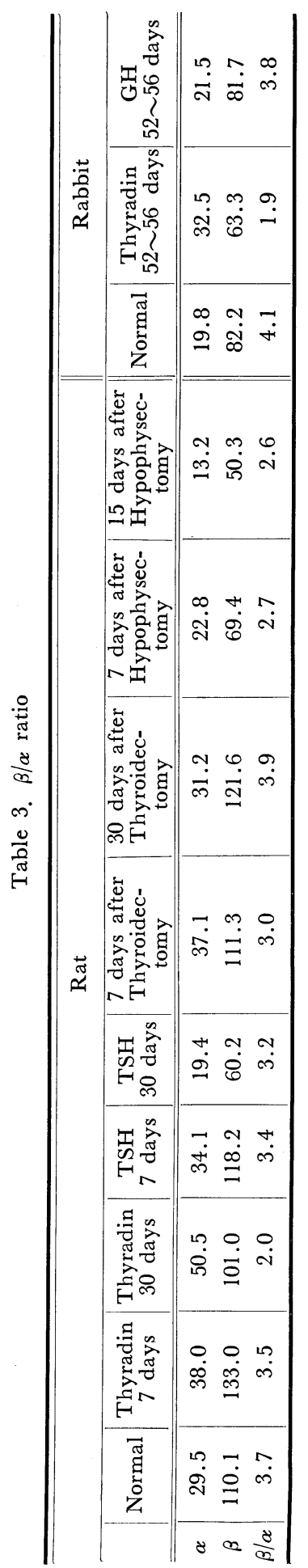

c） ラ氏島細胞核体積 : 健常ラット 3 匹90個のラ氏島の $\alpha$ 細胞核体積 は平均值 $70.7 \pm 1.9 \mu^{3}$ であり, $\beta$ 細胞核体積の平均值は $75.0 \pm 2.0 \mu^{3}$ であ る. 同じく家鬼では $\alpha$ 細胞核体積の平均值は $67.9 \pm 1.1 \mu^{3}, \beta$ 細胞核の それは平均 $72.9 \pm 2.0 \mu$ で，ラットのそれとほぼ同じ值を示している.

\section{第 2 節 Hormone 剂投与群}

\section{1) Thyradin 投与群}

1) CHP 染色及び Aldehyde fuchsin 染色所見

ラットにおける甲状腺製剤 Thyradin 30日間投与群では $\beta$ 細胞の胞 体は原形質が淡明となり，CHP 好性顆粒並びに aldehyde fuchsin 好 性顆粒は著明に減少を示し, sinusoidに面して少量の顆粒を認めるもの が多い。一部 $\beta$ 細胞は水腫様変性に陥入り, 空胞の出現を見る。核も明 らかな濃縮傾向を示し大小不同となり，核小体も縮小する， $\beta$ 細胞に以 上の如き退行変性像が見られる一方， $\alpha$ 細胞も phloxine 好性が稍々低 下しているが，核濃縮，空胞変性等は認められない. 然し同じく7 日間 投与群では両細胞共以上のような退行変性像は殆んどみられず僅かに $\beta$ 細胞顆粒の減少を示すに止まる。

家鬼に Thyradin 200mg/head を52〜56日間に亘つて投与した場合， 尿中還元物質は常に陰性で空腹時血糖値は 95〜 $120 \mathrm{mg} / \mathrm{dl}$ で正常範囲内 にあつた．乙の場合の膵ラ氏島は $\alpha$ 細胞は明らかに増殖を示すとともに 細胞体も肥大するが phloxine 好性顆粒は略々正常に保持される。一方 $\beta$ 細胞数は明らかに減少を来し $\alpha$ 細胞によつて圧排された如き観を呈す る。 $\beta$ 細胞は縮小するものが多く， $\beta$ 顆粒は明らかな減少を示すと共に 顆粒の偏在が強く認められる。

\section{2 ) Zn 染色所見}

ラットにおける Thyradin 7 日間投与群では $\alpha$ 細胞の黒色の好 銀 性 物質はやや減少するかに見えるがあまり著明でなく， $\beta$ 細胞のそれは正 常と殆んど変化の認められないものが多い. 一方同じく 30 日間投与群に おいては $\alpha \cdot \beta$ 両細胞における好銀性物質は著明に減少し，殊に $\beta$ 細胞に 於て著しい減少が見られる。

Thyradin 52〜 56日間投与の家鬼ラ氏島では， $\beta$ 細胞に於ては極めて 軽度の褐色を示し明らかに亜鉛顆粒の減少を認める。 $\alpha$ 細胞には家兔の 場合殆んど亜鉛は認少られない.

\section{3 ) SS-SH 基染色}

ラットにおいて，Thyradin 30日間投与群では細胞に於ける SS-SH 基物質は全般に稍々減弱するが殊に $\beta$ 細胞にその傾向か溞く認められる. 然し Thyradin 7 日間投与によつては対照群とさしたる変化は認められ なかつた。

\section{4) ラ氏島計測}

a ）ラ氏島面積 : ラットの Thyradin 30日間投与群では平均值は74.7 $\pm 13.1 \times 100 \mu^{2}$ であり，対照群に比してその面積は減少傾向が認められ るが，推計学的に有意の変化とは考えられない. 又同じく7 日間投与で は平均值 $98.2 \pm 11.5 \times 100 \mu^{2}$ で正常に比し著変は認められない.

Thyradin 52～56日間投与時の家鬼ラ氏島の面積は平均 $150.2 \pm 15.3$ 
$\times 100 \mu^{2}$ で, 刘照に比し增大を示す.

b) $\alpha \cdot \beta$ 細胞比：ラットに於ける Thyradin 30 日間投与群では $\alpha$ 細胞数は $50.5, \beta$ 細胞数は 101.0 を示し， 従つて $\beta / \alpha=2.0$ となり対照群に比して $\alpha$ 細胞の增加が認められる. 7 日間投与では $\beta / \alpha$ は 3.5 で稍々 $\alpha$ 細胞 の増加傾向がみとめられた. Thyradin 52〜56日間投与家鬼亏氏島の平均 $\alpha$ 細胞数は $32.5, \quad \beta$ 細胞数63.3で $\beta / \alpha=1.9$ となり対照に比し著しい $\alpha$ 細胞の增加を認める.

c) $\alpha \cdot \beta$ 細胞核体積 : Thyradin 7 日間投与ラットにおける $\alpha$ 細胞核体積の平均值は $64.5 \pm 3.7 \mu^{3}$ で対照群 に比し殆んぞ変化が認められない. 又 Thyradin 30日間投与ラットでも $\alpha$ 細胞核体積は対照と差咀はみら れない。一方 $\beta$ 細胞核体積は 30 日間投与群では平均值は $58.5 \pm 2.7 \mu^{3}$ で対照群に比し推計学的に有意の差を もつて減少し，7 日間投与群では反つて增加傾向を示したが有意の変動とはいえない. Thyradin 長期投与 の家鬼では $\alpha$ 細胞核体積は平均值 $72.9 \pm 2.2 \mu^{3}$ であり対照群より明らかに肥大し推計学的にも有意である. 一方 $\beta$ 細胞核体積は平均値 $68.1 \pm 2.6 \mu^{3}$ でほぼ対照群と同じ值を示している.

\section{II) TSH 投与群}

\section{1) CHP 染色及び Aldehyde fuchsin 染色所見}

ラットに於ける Pretiron 7 日間投与群では $\beta$ 細胞は細胞体の肥大傾向がみられる他， $\beta$ 顆粒は稍々減少傾 向がみられ辺縁化の傾向がうかがわれるが， $\alpha$ 細胞には著変は認められない，同じく 30 日間投与群では上記 変化は顕著となり $\beta$ 細胞の肥大, 顆粒の脱失, 顆粒が僅かに辺縁に残存し, 核染色質は微細顆粒状となり分 散して核は大きく明るく見元る。然し空胞変性, 水腫変性, 核濃縮等の退行性変化はみられない。 $\alpha$ 細胞は 比較的増殖か認められるが分泌顆粒は均等に細胞質に存在し特に変化は認められない.

\section{2) $Z n$ 染色所見}

TSH 7 日間投与群の $\beta$ 細胞では好銀性物質は減少し極く微弱な陽性を示すに止まるものが多い， $\alpha$ 細胞 には猶相当量の好銀性物質がみられる，TSH を30日間投与を継続すると， $\beta$ 細胞には殆んど全くZn とみ られる黒色沈着物は消失し去り僅かに $\alpha$ 細胞と思われるところに少量の沈着物をみるのみとなる.

\section{3 ) SS-SH 基反応所見}

7 日間投与の場合 $\beta$ 細胞の SS-SH 基の反応は反つて増強する傾向を認めるものが多いが，30日間投与で は同反応は増強するものと，減弱していると考えられるものが相半ばし一定の傾向は認められなかつた， $\alpha$ 細胞は殆んど変化を認めなかつた。

\section{4) ラ氏島計測}

a ）ラ氏島面積：TSH 7 日間投与及び30日間投与のラットラ氏島の面積は対照群に比し著明な変化は認 められない。

b) $\alpha \cdot \beta$ 細胞比 $:$ TSH 7 日間投与群及び30日間投与群共に著しい変化はみられなかつた。

c) $\alpha \cdot \beta$ 細胞核体積 : $\alpha$ 細胞核体積は 7 日間投与群では平均值 $64.3 \pm 2.1 \mu^{3}$ であつて正常又はやや縮小傾向 が認められるが推計学的に有意とは考元られない。一方 $\beta$ 細胞核体積は 7 日間投与群では平均值は $75.4 \pm$ $2.1 \mu^{3}$ を示し対照に比し変化はみられず，又 30 日間投与群では平均値 $80.4 \pm 2.4 \mu^{3}$ であり明らかな增大が認め られた。

\section{III) Growth hormone 投与群}

\section{1) CHP 染色及び Aldehyde fuchsin 染色所見}

成長ホルモン 1 日 $10 \mathrm{mg} / \mathrm{head} 52 \sim 56$ 日間投与の家鬼の血糖は何れも $120 \sim 140 \mathrm{mg} / \mathrm{dl}$ の範囲内にあつた が，尿糖を証明するものは認められなかつた，乙の場合のラ氏島の変化は， $\alpha$ 細胞は細胞数がやや增加し $\alpha$ 細胞核の肥大がみられる。 又 $\beta$ 細胞では顆粒が稍々減少し margination が著明となるが顆粒の量は必ずし も常に減少せず水腫変性その他の退行性変化は認められない，一方外分泌部, 小導管上皮より新生したと思 われる小ラ氏島が認められる。

\section{2) $\mathrm{Zn}$ 染色所見}

Silfid Silver Verfahren による好銀性顆粒は $\alpha ・ \beta$ 細胞共正常と殆ど変化を認めないものが多い. 


\section{3) ラ氏島計測}

a) ラ氏島面積：一般に大きなラ氏島の数が多くなり従つて平均面積も大となる.

b ） $\alpha \cdot \beta$ 細胞比 : $\alpha$ 細胞がやや增加し従つて $\beta / \alpha$ 比がやや小さくなる傾向を示すが推計学的に有意でない.

c) $\alpha \cdot \beta$ 細胞核体積 $: \alpha$ 細胞核体積は平均值 $75.5 \pm 1.8 \mu^{3}$ で対照に比しやや肥大の傾向を示し, $\beta$ 細胞核 体積のそれは平均 $70.6 \pm 3.2 \mu^{3}$ で正常のものと差異は認められない.

\section{第 3 節 内分泌腺剔除群}

\section{I) 甲状腺剔除群}

1) CHP 染色及び Aldehyde fuchsin 染色所見

甲状腺剔除後 7 日間生存群即ち甲状腺を全剔後一週間を経たラットの脺ラ氏島では $\beta$ 細胞は稍々縮小の傾 向を示しているが, hematoxylin 好性顆粒及び aldehyde fuchsin 好性顆粒は必ずしも減少を示さず細胞体 全体に霉漫性に存在している。 $\beta$ 細胞核は全体にやや大きく見光るが核染色質は践大となり散在している. 核小体に変化はみられない， $\alpha$ 細胞は顆粒，細胞核等に異常を認めない．甲状腺剔出後30日で屠殺したラッ トの膵ラ氏島では $\beta$ 細胞は細胞質が菱縮し所謂 $\beta$ 顆粒は桷漫性に胞体内に見られるが，全体として明らかに 減少し，反つて核周辺部に集まる傾向を示す，従つて $\beta$ 細胞は一般に明調に見えるものが多い．ての場合核 はやや縮小するものが多く，染色質が粗大化するため核質は明調部之暗調部がはつきりと認められるように なつてくる。核小体の肥大は認められない， $\alpha$ 細胞には著明な変化はみられない。

\section{2) $\mathrm{Zn}$ 染色所見}

甲状腺剔出 7 日後のラットでは $\beta$ 細胞に於ける好銀性物質は全体に濃い黑色を呈し，対照群と同程度乃至 それ以上の沈着がみられる。 $\alpha$ 細胞では正常に比しあまり変化がみられない，甲剔後 30 日のものでは $\alpha$ 細胞 には猶充分量の好銀性沈着物をみとめるが， $\beta$ 細胞は淡い褐色に染まる程度で著明な亜鉛の減少がみられる。

\section{3 ) SS-SH 基反応所見}

甲剔 7 日後の SS-SH 基反応は正常のものと殆んど差異を認めないが，30日後のものでは同反応は明らか に低下しているものが多くみられる。

\section{4) ラ氏島の計測}

a) ラ氏島面積 : 甲剔後 7 日のものでは平均 $105.2 \pm 11.2 \times 100 \mu^{2}$ で正常と比べてやや大きい傾向があるが 推計学的に有意ではない，甲剔後 30 日のものでは $96.8 \pm 9.7 \times 100 \mu^{2}$ で正常に比しラ氏島面積はやや小さくな つている.

b ) $\alpha \cdot \beta$ 細胞比 : 甲剔 7 日後の $\alpha$ 細胞数は37.1, $\beta$ 細胞数は111.3で $\beta / \alpha=3.0$ を示し, ほぼ正常值と考元 られる. 又尀剔後 30 日のものでは平均 $\alpha$ 細胞数 $31.2, \quad \beta$ 細胞数 121.7 で $\beta / \alpha=3.9$ であり, 対照と差異がみら れない.

c） $\alpha \cdot \beta$ 細胞核体積: 甲剔 30 日後の $\alpha$ 細胞核体積は平均 $61.0 \pm 2.1 \mu^{3}$ であり対照に比し稍々縮少し, $\beta$ 細胞核 のそれは平均 $70.5 \pm 3.1 \mu^{3}$ で明らかな縮小がみられる。闸剔後 7 日の $\alpha \cdot \beta$ 細胞核体積は夫々平均 $68.8 \pm 2.1 \mu^{3}$, $79.3 \pm 2.9 \mu^{3}$ で対照と殆んど差異を認めない.

\section{II) 下垂体剔除群}

\section{1) CHP 染色及び Aldehyde fuchsin 染色所見}

下垂体剔出後 7 日目ではラットは活動性が低下し，被毛が艶を失つて飼育箱の一隅に蹲まるようになる。 更に長期間生存 (15日間) せるものでは一層との状態か淜らかとなる。剔出後7 日群のラ氏島 $\beta$ 細胞は一般 に縮小し, GHP 顆粒及び aldehyde 顆粒は軽度に減少し, 細胞体全体に濔漫性に存在し, 正常ラットに見 られる如き sinusoid 亿面して顆粒が存在する傾向は全く認められなくなる。 $\beta$ 細胞核は縮小し，核染色質 は疎大分散化の傾向が著明となり核小体も明らかに縮小する。 $\alpha$ 細胞体は一般に小さくなり， $\alpha$ 顆粒の減少 傾向がみられる。剔出15日後のラ氏島では $\alpha \cdot \beta$ 細胞共上記の所見が著明となると共に一部の $\alpha \cdot \beta$ 細胞には 空胞変性，菱縮，核濃縮等の退行性変化が著明となる。

\section{2) $\mathrm{Zn}$ 染色所見}


Table 4 .

\begin{tabular}{|c|c|c|c|c|c|c|c|}
\hline \multirow{3}{*}{ Animal } & \multirow{3}{*}{ Treatment } & \multirow{3}{*}{$\begin{array}{l}\text { Duration } \\
\text { (days) }\end{array}$} & & & & \multicolumn{2}{|c|}{ Histochemical } \\
\hline & & & \multicolumn{5}{|c|}{$\alpha$ cell } \\
\hline & & & cytoplasm & granula & zinc & SS-SH & $\begin{array}{l}\text { nnucleus \& } \\
\text { nucleolus }\end{array}$ \\
\hline \multirow{9}{*}{ Rat } & Normal & & normal & filled & rich & weak & normal \\
\hline & \multirow[b]{2}{*}{ Thyradin } & 7 & no change & no change & no change & no change & no change \\
\hline & & 30 & $\begin{array}{l}\text { slightly } \\
\text { enlarged }\end{array}$ & $\begin{array}{c}\text { almost } \\
\text { no change }\end{array}$ & decreased & $\begin{array}{c}\text { decreased } \\
\text { or } \\
\text { no change }\end{array}$ & no change \\
\hline & \multirow{2}{*}{ TSH } & 7 & no change & no change & $\begin{array}{c}\text { slightly } \\
\text { decreased }\end{array}$ & no change & no change \\
\hline & & 30 & no change & no change & $\begin{array}{l}\text { markedly } \\
\text { decreased }\end{array}$ & no change & no change \\
\hline & \multirow{2}{*}{$\begin{array}{l}\text { Thyroid- } \\
\text { ectomy }\end{array}$} & 7 & no change & no change & no change & no change & no change \\
\hline & & 30 & no change & no change & no change & no change & no change \\
\hline & \multirow{2}{*}{$\begin{array}{c}\text { Hypophy- } \\
\text { sectomy }\end{array}$} & 7 & atrophy & $\begin{array}{l}\text { slightly } \\
\text { decreased }\end{array}$ & no change & no change & no change \\
\hline & & 15 & atrophy & decreased & $\begin{array}{l}\text { slightly } \\
\text { decreased }\end{array}$ & no change & contracted \\
\hline \multirow{3}{*}{ Rabbit } & Normal & & normal & filled & trace & weak & normal \\
\hline & Thyradin & $52 \sim 56$ & enlarged & $\begin{array}{c}\text { slightly } \\
\text { decreased }\end{array}$ & no change & & no change \\
\hline & $\mathrm{GH}$ & $52 \sim 56$ & no change & no change & no change & & $\begin{array}{l}\text { slightly } \\
\text { enlarged }\end{array}$ \\
\hline
\end{tabular}

下垂体剔出後7 日のラットのラ氏島では， $\beta$ 細胞では中等度の黒色の銀沈着物を認め対照群に比し变化が 認められないか，又はやや覀鉛顆粒の増量するものもみられる， $\alpha$ 細胞も対照に比べて著明な変化は認めら れない，15日後のものでは，好銀性顆粒はやや減少の傾向を示すがその程度は両細胞共あまり著明でない， 然しその存在部位は正常のものと異なり, 細胞体全体に㵢漫性に均等に存在し何らの極性を示すことはない.

\section{3 ) SS-SH 基反応所見}

下垂体剔出後 7 日のものでは両細胞共正常とそれ程異なつた所見を示さないが，30日後のものでは SS-SH 基反応は $\beta$ 細胞に於て明らかな減弱を示すものが認められた。

\section{4) ラ氏島計測}

a）ラ氏島面積：下垂体剔出 7 日後のものでは $101.0 \pm 10.0 \times 100 \mu^{2}$ で対照に比し変化は認められない．30 日後では平均 $81.6 \pm 15.4 \times 100 \mu^{2}$ で正常に比し稍々ラ氏島面積は縮小している.

b ) $\alpha \cdot \beta$ 細胞比 : 垂剔 7 日後のラットラ氏島では $\beta / \alpha$ 比は 2.7 であまり変化がないが，30日後では両細胞 共細胞数の減少が起り, 殊に $\beta$ 細胞の減少が著明に起るため, 比較的 $\alpha$ 細胞增加となつて $\beta / \alpha$ 比は2.6を示し ている.

c）ラ氏島細胞核体皘：垂剔後 7 日のラットラ氏島では $\alpha$ 及び $\beta$ 細胞核体積は夫々平均 $52.1 \pm 1.6$ 及び $63.2 \pm 2.2 \mu^{3}$ で何れも核体積の縮小がみられる. 30 日後ではての傾向は一層顕著となり，夫々平均 $58.8 \pm 2.7$ 及び $55.1 \pm 1.5 \mu^{3}$ で何れも明らかな縮小を示し，対照ラットに比して推計学的に有意な変化である。 
Summarized Table

\begin{tabular}{|c|c|c|c|c|c|c|c|c|}
\hline \multicolumn{5}{|c|}{ findings } & \multicolumn{4}{|c|}{ Mesurments } \\
\hline \multicolumn{5}{|c|}{$\beta$ cell } & \multirow{2}{*}{$\left|\begin{array}{c}\text { Dimension } \\
\text { of islet } \\
\left(100 \mu^{2}\right)\end{array}\right|$} & \multirow{2}{*}{$\begin{array}{l}\beta / \alpha \\
\text { ratio }\end{array}$} & \multicolumn{2}{|c|}{$\begin{array}{l}\text { nuclear } \\
\text { volume }\left(\mu^{3}\right)\end{array}$} \\
\hline cytoplasm & granula & zinc & SS-SH & $\begin{array}{l}\text { nucleus \& } \\
\text { nucleolus }\end{array}$ & & & $\alpha$ & $\beta$ \\
\hline normal & filled & middle & middle & normal & $\begin{array}{r}101.0 \\
\pm 14.6\end{array}$ & 3.7 & $\begin{array}{l}70.0 \\
\pm 1.9\end{array}$ & $\begin{array}{l}75.0 \\
\pm 2.0\end{array}$ \\
\hline no change & $\begin{array}{c}\text { slightly } \\
\text { decreased }\end{array}$ & $\begin{array}{c}\text { slightly } \\
\text { decreased }\end{array}$ & no change & no change & $\begin{array}{c}98.2 \\
\pm 11 \cdot 5 \\
\end{array}$ & 3.5 & $\begin{array}{l}64.5 \\
\pm 3 \cdot 7 \\
\end{array}$ & $\begin{array}{r}76.0 \\
\pm 3.2 \\
\end{array}$ \\
\hline $\begin{array}{c}\text { vacuolic, } \\
\text { hydropic } \\
\text { degeneration }\end{array}$ & $\begin{array}{l}\text { markedly } \\
\text { decreased }\end{array}$ & $\begin{array}{l}\text { markedly } \\
\text { decreased }\end{array}$ & decreased & $\begin{array}{l}\text { condensed, } \\
\text { contracted }\end{array}$ & $\begin{array}{l}74.7 \\
\pm 13.1\end{array}$ & 2.0 & $\begin{array}{l}66.8 \\
\pm 2.7\end{array}$ & $\begin{array}{r}58.5 \\
\pm 2.7\end{array}$ \\
\hline enlarged & $\begin{array}{c}\text { slightly } \\
\text { decreased, } \\
\text { margination }\end{array}$ & decreased & \begin{tabular}{|} 
slightly \\
increased
\end{tabular} & no change & $\begin{array}{l}107 \cdot 6 \\
\pm 14.0\end{array}$ & 3.4 & $\begin{array}{l}64.3 \\
\pm 2.1\end{array}$ & $\begin{array}{r}75.4 \\
\pm 2.1 \\
\end{array}$ \\
\hline $\begin{array}{c}\text { enlarged, } \\
\text { degeneration } \\
(-)\end{array}$ & $\begin{array}{c}\text { markedly } \\
\text { decreased, } \\
\text { margination }\end{array}$ & $\begin{array}{c}\text { almost } \\
\text { disappearance }\end{array}$ & $\begin{array}{c}\text { increased } \\
\text { or } \\
\text { decreased }\end{array}$ & $\begin{array}{c}\text { enlarged, } \\
\text { light }\end{array}$ & $\begin{array}{l}100.1 \\
\pm 12.4\end{array}$ & 3.2 & $\begin{array}{l}70.2 \\
\pm 3.2 \\
\end{array}$ & $\begin{array}{r}80.4 \\
\pm 2.4\end{array}$ \\
\hline $\begin{array}{c}\text { slightly } \\
\text { contracted }\end{array}$ & $\begin{array}{c}\text { no change, } \\
\text { diffuse }\end{array}$ & $\begin{array}{c}\text { no change } \\
\text { or } \\
\text { increased }\end{array}$ & no change & $\begin{array}{l}\text { slightly } \\
\text { enlarged, } \\
\text { no change }\end{array}$ & $\begin{array}{l}105.2 \\
\pm 18.2\end{array}$ & 3.0 & $\begin{array}{l}68.8 \\
\pm 2.1\end{array}$ & $\begin{array}{r}79.3 \\
\pm 2.9 \\
\end{array}$ \\
\hline atrophy & $\begin{array}{l}\text { decreased, } \\
\text { diffuse }\end{array}$ & $\begin{array}{l}\text { markedly } \\
\text { decreased }\end{array}$ & decreased & $\begin{array}{l}\text { slightly } \\
\text { contracted, } \\
\text { gross } \\
\text { chromatin }\end{array}$ & $\begin{array}{r}86 \cdot 8 \\
\pm 9 \cdot 7\end{array}$ & 3.9 & $\begin{array}{l}61.0 \\
\pm 2.0\end{array}$ & $\begin{array}{r}70.5 \\
\pm 3.1\end{array}$ \\
\hline atrophy & $\begin{array}{l}\text { slightly } \\
\text { decreased, } \\
\text { diffuse }\end{array}$ & $\begin{array}{l}\text { no change or } \\
\text { slightly } \\
\text { increased }\end{array}$ & $\left|\begin{array}{c}\text { no change } \\
\text { or } \\
\text { decreased }\end{array}\right|$ & $\begin{array}{l}\text { contracted, } \\
\text { gross } \\
\text { chromatin }\end{array}$ & $\begin{array}{l}101.0 \\
\pm 10.0\end{array}$ & 2.7 & $\begin{array}{l}52.1 \\
\pm 1.6\end{array}$ & $\begin{array}{r}63.2 \\
\pm 2.2 \\
\end{array}$ \\
\hline \begin{tabular}{c|} 
atrophy, \\
vacuolic \\
degeneration
\end{tabular} & $\begin{array}{l}\text { decreased, } \\
\text { diffuse }\end{array}$ & $\begin{array}{l}\text { slightly } \\
\text { decreased, } \\
\text { diffuse }\end{array}$ & decreased & $\begin{array}{l}\text { condensed, } \\
\text { contracted }\end{array}$ & $\begin{array}{l}81.6 \\
\pm 15.4\end{array}$ & 2.6 & $\begin{array}{l}58.8 \\
\pm 2.7 \\
\end{array}$ & $\begin{array}{r}55.1 \\
\pm 1.5 \\
\end{array}$ \\
\hline normal & filled & $\begin{array}{l}\text { middle or } \\
\text { rich }\end{array}$ & middle & normal & $\begin{array}{l}122.3 \\
\pm 14.3\end{array}$ & 4.1 & $\begin{array}{l}67.9 \\
\pm 1.1\end{array}$ & $\begin{array}{r}72.9 \\
\pm 2.0 \\
\end{array}$ \\
\hline $\begin{array}{c}\text { slightly } \\
\text { contracted }\end{array}$ & $\begin{array}{c}\text { decreased, } \\
\text { margination }\end{array}$ & decreased & & contracted & $\begin{array}{l}150.2 \\
\pm 15.3\end{array}$ & 1.9 & $\begin{array}{l}72.9 \\
\pm 2.2\end{array}$ & $\begin{array}{r}68.6 \\
\pm 2.6\end{array}$ \\
\hline no change & $\begin{array}{c}\text { slightly } \\
\text { decreased }\end{array}$ & no change & & no change & $\begin{array}{l}131.8 \\
\pm 13.6 \\
\end{array}$ & 3.8 & $\begin{array}{l}75.5 \\
\pm 1.8 \\
\end{array}$ & $\begin{array}{r}70.6 \\
\pm 3.2 \\
\end{array}$ \\
\hline
\end{tabular}

\section{第 5 章 総括}

以上下垂体甲状腺系ホルモンの膵内分泌に及ぼす影響について形態学的に検討した成績を総括すると次の 如くである. (Table 4)

1 ）正常群 : 正常ラットのラ氏島計測值ではラ氏島面積は平均 $101.4 \pm 14.6 \times 100 \mu^{2}$ で $\beta / \alpha$ 細胞比は 3.7 ,

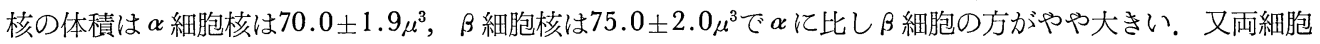
共細胞質，核及び核小体は形態的に変化なく，顆粒及び西鉛は中等乃至多量に認められる．SS-SH基物質は $\alpha$ 細胞では極めて弱く検出される程度であるが， $\beta$ 細胞では外分泌部に比して弱いが $\alpha$ 細胞よりは明らかに 強く存在する. 正常家鬼のラ氏島面積は平均 $122.3 \pm 14.3 \times 100 \mu^{2}, \beta / \alpha$ 比は4.1となつている. 核体積は $\alpha$ 細

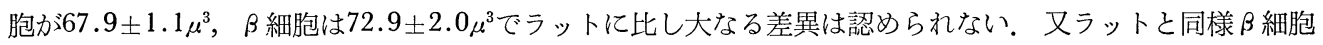
核体積は $\alpha$ 細胞のそれより稍々大きい，顆粒の存在様式はラットと本質的に何ら異なるとてろはないが，亜 鉛のそれはラットと著しく異なり， $\beta$ 細胞には多量に存在するが $\alpha$ 細胞には極めて微量しか存在せず，従つ て組織切片上にて淡褐色に検出される程度である。

2) Thyradin 投与群: ラットに Thyradin $20 \mathrm{mg} / 100 \mathrm{~g} 7$ 日間投与群では $\alpha$ 細胞には殆ど全く変化は認め られないが， $\beta$ 細胞では顆粒が稍々減少するものが多く又亚鉛も同様の傾向を示した。 $\beta$ 細胞核は統計的に 有意ではないが肥大が認められ，核小体は不変と見なされる， $\beta / \alpha$ 比は $3.5 て ゙$ 有意の変動は認められない。

同じく Thyradin を 30 日間投与した群では上述の所見と明らかに異なり $\beta$ 細胞は水腫変性及び空胞変性 
が認められ，核は濃縮し大小不同となり，顆粒は著明に減少し且つ血管極に集合する所見がみられる．亜鉛 も著明に減少し，更に SS-SH 基物質も減少を示した。 $\alpha$ 細胞は CHP 染色所見の上では殆んど全く変化を 認めなかつたが， $\alpha$ 細胞の西鉛のみ明らかに減少を示すものが多くみられた。計測値ではラ氏島面積は減少 の傾向が認められたが $\alpha$ 細胞は著変なく， $\beta$ 細胞核の体積は $58.5 \pm 2.7 \mu^{3}$ で正常に比し明らかな縮小を示し ている. 又 $\beta / \alpha$ 比は明らかな低下を来し平均 2.0 となる。

次に家鬼に Thyradin 200mg/head 52〜 56日間に亘つて長期投与を行なつた際のラ氏島の変化は前述う ットに於ける成績と本質的な差異は認められないが, 即ち $\beta$ 細胞は萎縮の傾向を示し, 核は濃縮傾向があり 計測的にも明らかな縮小か認められ，又 $\beta / \alpha=1.9$ と明らかに低下してれは $\alpha$ 細胞の絶体数の増加に基づく ものであり形態的にも $\alpha$ 細胞体の肥大を示した。 $\beta$ 顆粒も減少し亜鉛も著明に減少した.

3) TSH 投与群 : ラットに TSH 10JSU/100g 7 日間投与した場合のラ氏島では $\alpha$ 細胞は亜鉛の脱失が軽 度に起つている程度で他は全く無変化と云つてよい， $\beta$ 細胞では顆粒がやや減少し血管極に辺縁化する傾向 が表われ，亜鈶は減少し，SS-SH 基物質は僅かに增量するが核小体，ラ氏島面積並に $\beta / \alpha$ 比は正常と変り がない.

次に TSH を同量30日間投与後のラ氏島では $\alpha$ 細胞は亜鉛の著明な減少を見る以外計測上にも変化は認 められないが， $\beta$ 細胞では顆粒の減少と辺縁化，亜鉛の殆んど消失に近い程度のものを含めての著明な減少 を示すが，SS-SH 基反応は強く出るものと反つて減少傾向がみられるものと相半ばして一定の傾向はみら れなかつた。一方 $\beta$ 細胞核は肥大し明調となり核小体も肥大し，計測的にも明らかに高值を示している.

4) 成長ホルモン投与群 : 成長ホルモンを52〜56日間に亘つて投与した家鬼では $\beta$ 細胞はやや縮小し，顆 粒は軽度減少し亜鉛も稍々減少する，又導管上皮よりの島新生が見られるが $\beta / \alpha$ 比， $\beta$ 細胞核体積には変化 を認めない， $\alpha$ 細胞では核体積がやや増大を示したが他に著明な変化はなかつた。

5 ) 甲状腺剔出群 : ラット甲状腺剔出 7 日後のものでは $\alpha$ 細胞は顕微鏡的にも計測的にも殆んど認むべき 変化はなかつたが， $\beta$ 細胞では細胞体が収縮傾向を示すと共に核染色質の疎大化がるられる，一方顆粒は量 的には減少は認められないが，胞体内に均等洆漫性に分布し正常細胞に於てみられる程度の顆粒の辺縁化す らみられなかつた，悪鈶量は正常と変化がないか，又は反つて増量しているものも見られたが，SS-SH基反 応は変化をみないようである。計測上は認むべき変化を来さなかつた。

甲状腺剔出後 30 日でも $\alpha$ 細胞は核の体積の減少を見る他殆んど認むべき変化は見られなかつたが， $\beta$ 細胞 には明らかな変化を認めた。即ち $\beta$ 細胞は全体として萎縮し，顆粒及び亜鉛は明らかに減少し，顆粒に核周 辺部に集まる傾向を示し，SS-SH 基物質も減少した。計測的にはラ氏島面積の縮小， $\beta$ 細胞核体積の明ら かな縮小がみられた。

6) 下垂体剔出群：ラット下垂体剔出 7 日の群では $\alpha$ 細胞は胞体，核共に稍々菱縮を示すが，顆粒，覀鉛 量は共に正常と変りがない， $\beta$ 細胞は $\alpha$ 細胞と同様胞体は萎縮し一部に空胞変性をみとめ，顆粒は軽度減少 乙胞体内に渎漫性に存在し極性を示さない，又覀鉛は不変乃至稍々増加し核は稍々縮小を示した。

下垂体剔出15日後のラ氏島では上述の変化が一首顕著となり両細胞の核の濃縮が一層強く, $\beta$ 細胞は胞体 の萎縮, 空胞变性, 顆粒の減少と極性の消失, 业鉛の軽度減少, SS-SH 基反応の軽度な減弱がみられる. 又 ラ氏島平均面積も減少を来した。

\section{第 6 章 考按}

下垂体甲状腺系ホルモンの催糖尿病性作用については Houssay ${ }^{122) 3)}$ その他多くの人達により研究されてい るが，その多くは生化学的なものでありラ氏島の形態学の観察よりなされたものは少ない. 従つて之ら内分 泌腺ホルモンのラ氏島の形態に及ぼす影響とその意味づけについては殆ど全く知られていないと云つてよい． そてで著者はてれらホルモンの膵内分泌に及ぼす影響を形態学的に把握し, 出来れば形態と機能との関連に ついても検討せんと企て，上述の成績を得た。 ラ氏島の形態学は 1939年 Gomori 氏 ${ }^{11)}$ の CHP 染色法以来急 速な進歩をとげ更に Barrnett の DDD 法による Insulin 染色，その他の組織化学的方法によつてラ氏島の 
機能的細胞学の誕生を見るに至つた，形態と機能とは極めて密接不離な関係にあるべき筈でありながら，て の両者の相関を確立するてとは至難の事とされている。然し乍らラ氏島は主として 2 種類の細胞に限られて おり而も夫々の分泌するホルモンが明らかとなつているため，他の組織に比較して形態より機能を類推する てとは可能と考えられる. 私が本研究に於て敢えてての問題についても検討した所以である.

\section{ラ氏島細胞の機能的形態学}

ラ氏島特に $\beta$ 細胞の持つ特有な顆粒に初めて着目したのは Laquesse ${ }^{12)}$ であるとされる， その後前述の如 く初めて Gomori が chrom-hematoxylin-phloxine (CHP) 染色を行なうことによつてラ氏島 $\alpha \cdot \beta$ 細胞を明 らかに染別して以来，てれが CHP 好性顆粒（Gomori 顆粒）と呼ばれている．その後同じく Gomori ${ }^{13}$ 亿 よつて Aldehyde fuchsin による染色法が唱導され，本法による $\beta$ 細胞顆粒の消長は抽出される Insulin 量 との間に良好な相関があるとされている，従つて aldehyde fuchsin 法は Insulin 顆粒に対する特異性の 点で在来の染色法にまさるものと考元られる。乙の $\beta$ 細胞顆粒が Insulin そのものか, Insulin の貯蔵型か 或いは Insulin の precursor かという問題については, 種々墖議されたが Bell, ${ }^{14)}$, Hartrof ${ }^{15)}$, Wrenshall ${ }^{16)}$ 等は $\beta$ 顆粒と Insulin 量との平衡関係を糖尿病患者及び肥満マウスの膵インシュリン定量と染色所見との比 較によつて追及し，AF 法による $\beta$ 顆粒が Insulin 量とは必ずしも完全な平衡関係にないてとを見出し，乙 の顆粒が Insulin そのものではなくて，貯蔵型 Insulin 又は Insulin の precursor であろうと主張した。 然し Monike 等 ${ }^{24}$ によれば Gomori 顆粒は所謂 stored Insulin であり従つて必要に応じて直ちに放出さ

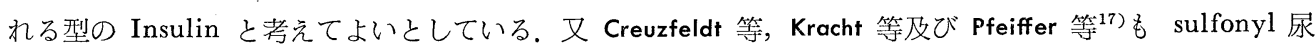
素剤投与後の Gomroi 顆粒の消失から之と類似の考帛を述べてい。. 殊に Pfeiffer は你牛のラ氏島より Insulin を抽出して Gomori 顆粒との平衡関係を一定条件下で認めている，以上のてとより吾々は $\beta$ 細胞中 には光学顕微鏡によつてとらえられない Insulin 又はその前階程物質があるものと考えざるを得ない.ての ような GHP 顆粒又は, aldenyde fuchsin 顆粒の增减が果して如何なるラ氏島機能の表現と見るべきであろ うか，今仮に $\beta$ 細胞にのみ限つて顆粒の消長についてみると，顆粒の著明な減少はその生成の減退と放出の 促進とが考えられる，前者は細胞機能の低下であり，後者はその元進状態の表現と見てょい．との場合 Gomori 顆粒の消長のみでは全く相異なつた二つの機能状態を鑑別するてとは出来ない，唯一般に放出の促 進による顆粒の減少の時は，少量の顆粒は細胞周辺部殊に sinusoid に面して所謂 margination の状態を 呈すると云われ，乙れは sulfonyl 尿素剂投与時に屡々見られる現象で吾々もての所見を確認している ${ }^{18) 19}$. 最近の研究によると ${ }^{20)}$ Aldehyde fuchsin で染色される $\beta$ 顆粒は Insulin を含んでいる sac menbrane が 染色されたものであろうと云う。とのととは電顕で高血糖脬発物質投与後 12 時間以内に顆粒の消失がおて るが，24〜48時間に至つて空になつた sac menbrane が存在するのが見られるという ${ }^{21)}$. 一方1942年岡本 ${ }^{22}$ により始めて膵ラ氏島に棘鉛が検出されて以来两鉛のラ氏島に於ける存在意義について論じられ，糖代謝に 影響を及ぽすような諸条件によりラ氏島内西鉛の增減が見られる点から一般に亜鉛がラ氏島の内分泌に密接

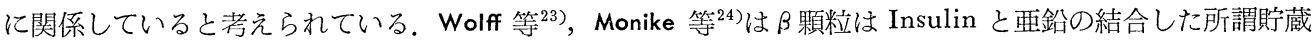
型 (Stopel form) であるとし，Peterson 等25)は抽出結晶インシュリン中に亜鉛が含まれ，in vitro で亜鉛 は Insulin の溶解度を下げて沈澱物を作るととから亜鉛がラ氏島 $\beta$ 細胞内の Insulin 貯蔵に関与すると述 べており，現在はての考方方が支配的である，従つてラ氏島 $\beta$ 細胞におけるZn の減少は Insulin 需要の䒕 進によつて貯蔵型より遊離型となつた Insnlin が放出されつつある状態又は前述 Gomori 顆粒の場合と同 ビくInsulin 生成の低下状態と考えられる，以上の如くGomori 顆粒及び亜鉛のみではラ氏島細胞の機能 をうかがうことは出来ない，一方 Barrnett 及び Seligman ${ }^{26 ~ 28)}$ は $\beta$ 細胞で産生される Insulin 分子はその構 成アミ酸の $12 \%$ cystin を含み分子量 6000 の最低分子は夫々 21 乃至 30 個の A chain, B chain が -S-S結合をなして分子量 12,000 の Monomer を形成するととより, 蛋白結合性 SS 基及び SH 基の組織化学的検 出法を考案してれを Insulin 染色法として発表した。 即ち pure crystal Insulin を0.2Nの塩酸溶液で沈澱 させその沈渣について Thyoglycolic acid でSS 基を SH 基還元し更に DDD $\left(2 \cdot 2^{\prime}\right.$-dihydroxy-6-6'-dinaphthyldisulfide) で酸化物とし，てれを Naphthanyl diazablue B で有色のアゾ色素に変化させる方法に 
より本法は Insulin に対して有用な検出法であるとして組織切片上でての反応を再現した。そして Barrnett 等は組織化学的に $\beta$ 顆粒と蛋白結合性 SH 及び SS 基は平行するばかりか一層真実に近い Insulin 量の目安 となるととを強調した， Lazarow ${ }^{29}$ も SH 基は Insulin 合成に重要な意義を有するてとを報告している，即 ち分子量 6,000 程度の Insulin の一次分子のペプタイド結合は SH 基か酸化して SS 基となることによつて他 の一次分子と結合するものでありその場合の触媒作用はグルタチオンであると推定している．何れにしても 前述の如くラ氏島 $\beta$ 細胞には光顕によつて把握するてとの出来ない溶解性の Insulin 又は precursor が存 在すると考えざるを得ないが，SS，SH 基の検出はてれらのものをも検出するてとが可能と一般に考えられ ている. 然し作ら Pfeiffer 等が云うまでもなく本法による染色性の強弱の判定は多分に主観的なものである ので，Bahr ${ }^{30)}$ は光度計を使用して定量的観察を試みている。しかしての方法とても組織切片上で行なわれる 他の光度計による定量と同様種々の難点があるのは止むを得ないととである. 本法によつて検出される $\mathrm{SH}$, SS 基は果して Insulin のどの type を表現しているかと云うことになると猶可成りの問題が残されている と思われるが Pfeiffer 等は本法は Insulin 又はその前階程物質を検出するものと信じている。確かに Sulfanyl 尿素剤投与後の SS-SH 基の extinction の程度は膵より抽出された Insulin 量と良好な平行関 係を示すにも拘らず $\beta$ 顆粒との間に discrepancy が見られるてとより首肯されるとてろである. 従つて本法 においてもその意義を諭ずる場合, 生成と分泌との問題が常に表裏の関係において存在すると考えねばなら ない，てれを要するに之等ラ氏島の染色法のみによつて細胞の機能を云々するてとは極めて危険なととと云 わねばならない，従つててれ以外に最も重要な機能状態をしる目安の一つはう氏島の計測による方法である

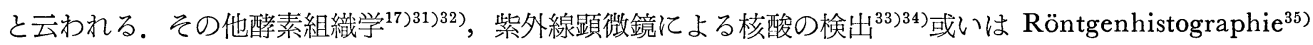

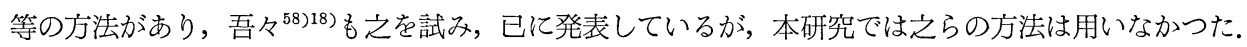

そてで次にラ氏島計測の意義について文献的考察を試みるてとにする，ラ氏島面績（容積，直径，重量）

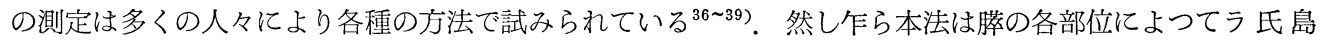
の大きさが異なると云うとと，小さなラ氏島は見逃され易く従つて比較的大きなもののみが測定される可能 性のあること等の欠点がある，又単にラ氏島そのものを測定するととはあまり意味がないとし，従つて膵臓 全重量との関係においてう氏島重量を考えるべきとするもの ${ }^{40741)}$ 或いは膵重量のみならず体重との関連に於 て考えるべきものとするもの (Haist and Pugh) ${ }^{36}$ 等がある。乙れらの制限があるにも拘らずう氏島の面積 乃至体積の測定は $\alpha \cdot \beta$ 細胞比との関係に於て見るならば可成りの規準的価值を有するものと考元られてい $ろ^{4243)}$. 次に $\alpha \cdot \beta$ 細胞の割合 (比率) は膵の各部位に於て一定していると考えられており ${ }^{44}$ ，その意味で両 細胞比の変動は有力な機能の指標となりうる可能性がある. 然し乍らての方法をもつてしては $\alpha \cdot \beta$ 細胞の 増加乃至减少が絶対的であるのか，相対的であるのか明らかでなく又人の糖尿病に於ても必ずしも常に $\alpha$ 細 胞の比率の増大が存在するとは限らない45 47)ばかりか, Seifert によれば悪性腫晹, 悪液質, 結核, 尿毒症 等に於ても同様な所見が見られることがあると云われる. 又 Kracht は Alloxan, Synthalin A 又は IPTD の如き化学物質を投与した場合， $\alpha \cdot \beta$ 細胞比の変動は明らかに起つてくるけれぞも，ホルモン投与時又は 血糖の変動時にはその比率の変動は起らないとして $\beta / \alpha$ 比の島の機能診断上の意義をあまり重要視していな い. 上述の $\alpha \cdot \beta$ 細胞比に反して両細胞核の大きさは機能診断的に大きな意義を有すると考えられる. 最も 最初にラ氏島の核の計測を行なつたのは Bakay ${ }^{48}$ 及び Güthert ${ }^{49)}$ である. Güthert は下垂体の刺激時にラ氏 島細胞の核の大いさの変化をみてラ氏島に及ぼす下垂体の影響について詳細に論じている。 その後 Tonutti 及び Grobetz は正常ラットの $\alpha$ 細胞核体積は $\beta$ 細胞のそれより小さいととをのべると共に両細胞核の变動 の範囲を示した，更に多くの報告者は50) 533 種々の条件下における核体積の測定を試みこれと機能との関連 そついて詳細な研究をとげている．就中 Kracht はラ氏島の計測中最も重要なものとして核のそれをあげ各 種ホルモン投与時及び内分泌腺剔出時について報告し機能立進時には核体積の増大が起り，低下時には縮小 するてとを多く成績によつて証明している．Insulin の合成は多分に仮説的ではあるが一般に次のように考

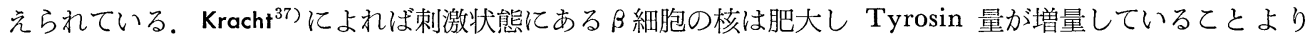
$\beta$ 細胞核の肥大は蛋白質の増加が原因であると云う。これらの核の非ヒストン蛋白は細胞体における蛋白合 
成 (Insulin) の材料として提供されると考光られている. 血中のアミノ酸から細胞核中にとり入れられた蛋 白合成のための材料は核小体の関与の下に細胞体内に出てゆきそてで RNA glutathion の存在下に Insulin が合成される. 合成された Insulin は直ちに細胞外飞放出されるか又は貯蔵型として細胞内に貯えられる. ての場合ミトコンドリア，クロマチンが之に関与していると考えられている．従つて形態的に $\beta$ 細胞の機能 を診断する場合は核の大きさ，核のクロマチン，核小体の態度，SS-SH 基の検出及び Gomori 顆粒と亜鉛 の検出が最も本質的な意義を有するととになる.

てれを総括的に表示すると次のようになる。

Criteria of diagnostic difinition of $\beta$-cell activity

\begin{tabular}{|c|c|}
\hline inactiv & activ \\
\hline $\begin{array}{l}\text { Atrophy of nucleus and nuclear hyper- } \\
\text { chromasia. } \\
\text { Contraction of nucleolus. } \\
\text { Intensive granulation in secretionstop } \\
\text { and continuous production. } \\
\text { Decreasing granula with decreasing } \\
\text { secretion and production. }\end{array}$ & $\begin{array}{l}\text { Nuclear hyperplasia and nuclear hypo- } \\
\text { chromasia. } \\
\text { Enlargement of nucleolus. } \\
\text { Increase of mitosis. } \\
\text { Degranulation, hypogranulation, hydro- } \\
\text { pic degeneration. } \\
\text { Increase of protein bound sulfhydryl } \\
\text { and disulfide groups. } \\
\text { Increase of dimensions of Langerhans' } \\
\text { islets (various sizes). }\end{array}$ \\
\hline
\end{tabular}

\section{成績に対する考察}

\section{a ) Thyradin投与の影響}

前述の総括の項に於て記述した私の成績をラ氏島の機能的診断の criteria よりみれば, ラットに Thy$\operatorname{radin} 7$ 日間投与後のラ氏島では $\beta$ 細胞顆粒の軽度な減少, 覀鉛の減少並に $\beta$ 細胞核の肥大等の点よりして $\beta$ 細胞に於けるInsulin の生産が元進し乍らも猶咛蔵 Insulin の放出が之を上迴つている状態と解釉出来 るのであつて核の肥大，顆粒の顕著な辺縁化等は之を物語るものと云つてよい．然し $\alpha$ 細胞には明らかな変 化はない，更に Thyradin を比較的長期（30日）に亘つて投与すると $\beta$ 細胞は機能过隹状態か持続するため 疲供状態に陷入り更に水腫様変性又は空胞変性等の退行性変化を招来するものと考えられる。乙の時は已に 核は明らかな濃縮縮小を示し， $\beta$ 顆粒はInsulin の生产の低下と放出の艺進のため著明に原形質中より脱失 し僅かに血管極に残存するのみとなる，亜鉛及び SS-SH 基反応の減少はてれを裏付ける所見である。 $\alpha$ 細 胞はての時期に到つても形態的に著変なく只 $\beta / \alpha$ 比のみ明かに低下し， $\alpha$ 細胞の肥大が軽度に認められる 程度である。

次に家兔に Thyradin を長期（52〜 56日）投与後では上述ラットの場合と略同様で $\beta$ 細胞は機能の㠵進 の時期を通り疲墴の状態に陥入りつつあると推定される所見であつて，ラットの場合と本質的に何ら異らな い. 唯投与量がラットに比して稍々少ないため $\beta$ 細胞の退行性変化はそれ程明かではなかつた。 ての場合も $\beta / \alpha$ 比は 1.9 と明瞭に低下し $\alpha$ 細胞の增殖がみられ $\beta$ 細胞系の活性の低下に伴う $\alpha$ 細胞系優位の機能的状態 を示した. Kracht, ${ }^{55)}$, Mornike ${ }^{56)}$ にれば Alloxan, 塩化コバルト, IPTD 等の化学的物質による処置を除 いて普通量の hormone 投与で $\beta / \alpha$ 比は普通変化しないとしているが, 室根 ${ }^{57)}$, 青地 ${ }^{58}$ そよれば AGTHの 長期投与によつて $\beta / \alpha$ 比の顕著な低下を証明しており，私の Thyradin 長期投与に見られる $\alpha$ 細胞の絶体 数の增加とよく似た所見を報告している。，一般に $\alpha$ 細胞は種々の外的条件に対する反応が $\beta$ 細胞に比して極 めて遅いてとは一般によく知られているとてろであり，形態的には殆んど変化を来さない細胞であるが，種 々の条件 AGTH, Glucagon, $\mathrm{CoCl}_{2}$ 等 $\left.^{57}\right)^{59}$ 亿対して数の上で比較的敏感に反応すると考えられる.ささて状 腺ホルモンを含むThyradinが膵ラ氏島に対して上述の如き変化を来すのは如何なる機作によるのであらう

$$
\text { 第 } 40 \text { 巻 第 } 7 \text { 号 }
$$


か. 甲状腺ホルモンが Insulin 亿対して拮抗作用をもつととは古くより知られた事実である．又甲状腺機 能六進時に尿糖の発現が明らかに高い頻度であらわれ Lahey ${ }^{6}$ の統計がよくてれを示している，又甲状腺機 能六進者では空腹時血糖は略々正常であるが，糖質掑取後の過血糖は高度に出現することは屢々吾人の経験 するとてろである。一方甲状腺機能充進時には比較的しばしば糖尿病の合併を見る. Joslin ${ }^{60)}$ とれれば，乙 の両者の合併は1.0〜 3.3\%で非糖尿病者の約 3 倍であるとのべている. 又 Regan 等 ${ }^{61}$ は Hyperthyroidism の約半数に Diabetes を起すと云い，Root ${ }^{43}$ も同様の成績をあげている．てのような甲状腺機能元進による 糖尿, 又は糖尿病の出現は甲状腺ホルモンの糖原蓄積の抑制と分解の六進と云う Adrenergic action と末 梢組織に於けるブドウ糖の利用乃至酸化を促進し，Insulin 需要の亢進がおてると考えられている，又甲状 腺機能え進時には腸管からの糖の吸収が方進しているとともその原因の一つと考えられている。乙れらは人 における成績であるが，藤田 $\left.{ }^{63}\right)$ の研究によると Thyradin 投与白鼠の肝臓においては glycogen の分解が 盛んであると同時に phosphohexose isomerase (PHI) の活性増加, pyruvate の減少の諸点から糖分解も 盛んに行なわれており, 又一方 fructose-1.6-diphosphatase の著明な増加, pyruvate の減少等から糖新生も 盛んとなつていると考觉られ，乙れらのととから一応 Thyroxine 投与白鼠においては血糖の上昇が起ると 推測される.末梢組織においても PHI, hexokinase の活性增加並びに glycogen, pyruvate の減少のある ことから glycogen の分解, 糖の分解が盛んに行なわれているものと考元られると述へている，てれらの臨 床的並に実験的結果より考光ると上述の私の成績は Thyradin 投与によつて Insulin 需要の增大に基づい て二次的なラ氏島 $\beta$ 細胞の機能九進と, それに引続く $\beta$ 細胞の exhaution から更に $\beta$ 細胞の機能低下によ る Insulin 産生の減少と云う一連の機能的 process を示すものと考光られる. Eppinger ${ }^{64)}$, Mc Callum $^{65}$ Friedmann ${ }^{66)}$ 等によれば甲状腺ホルモンはラ氏島機能を低下させると云うが，六進を通じてやがて低下する ものと解釈したい.

\section{b ) TSH 投与の影響}

ラットに TSH を比較的短期間 ( 7 日間)投与した場合， $\beta$ 細胞の顆粒の軽度減少，亜鉛の減少がみられ SS-SH 基反応は反つて増強の傾向を示すてとは軽度の Insulin 放出の促進か起つているものと考元られる。 この場合核及び核小体増大がみられないととは未だ Insulin の生合成の充進が起つていないととを示すもの ではなかろうか. 同じくTSH を30日間投与せる場合は $\beta$ 細胞の顆粒及び亜鉛の減少がおてり殊に後者が著 明におてるてとは強い Insulin 放出促進のため貯蔵 Insulin の消失に近い状態と推察出来る。一方に於て 核及び核小体の明らかな肥大と SS-SH 基の増加乃至減少という変動は Insulin 生成の克進を示しているも のと考えられる. 然しての場合 Thyradin 長期投与時にみられた如き $\beta$ 細胞の退行性変化は認められない処 よりすれば疲僙の状態まで進んでいるとは考えられない。

TSH は云うまでもなく下垂体前葉より分泌される向甲状腺ホルモンであつて甲状腺 ホルモンの生成と分 泌を支配する．従つて私の得た上記の成績が Thyradin 投与時のそれと或程度相似であるてとは当然と考 えられる. 然し乍ら TSH 投与の影響は本研究に用いた投与量では Thyradin 投与時に比して遙かに弱い 作用をラ氏島に対して発揮しているようである. 即ち TSH 投与によつて惹起されるであろう甲状腺ホルモ ンの分泌過多による影響はラ氏島の機能を亢進せしめるに止まつたと考えられる， $\alpha$ 細胞では著明な亜鉿の 脱失が見られたがラット $\alpha$ 細胞の亜鉛の意義については現在のとてろ明らかでなく，従つてその脱失の意義 についても不明と云う他はないが，推測が許されるなら $\beta$ 細胞の機能尣進に伴つて $\alpha$ 細胞の機能も元進した のかも知れない.

TSH の糖代謝に及ぼす影響は小島息 ${ }^{67)}$ とれば，TSH 注射により白鼠の空腹時血糖は僅かに高くなり， 横隔膜の糖利用は六進するが，肝の糖原合成は低下を来すという。しかし in vitro 亿於ける TSH 添加実 験では肝，筋の組織代謝に著変を来さないとし，TSH の糖代謝作用は甲状腺を介して行なわれるものとし ている. 一方 Horsters ${ }^{68)}$ は下垂体の向甲状腺ホルモン亿鬼の血糖を下降させる作用のあるととを報告し，

Zunz 及び LaBerre ${ }^{69}$ は同ホルモンがラ氏島の Insulin 分泌をたかめ得たと述べている. 又富田70)の in vitro に於ける添加実験によると TSH (Pretiron) の低濃度では変化は見られないが，その高濃度は Insulin 効 
果に対する阻害作用を示したという. 又馮場 ${ }^{71}$ はTSH で子め処理した鬼に於て普通発症せしめ得る量より も少量のアロキサン注射により十分糖尿病が発症し，組織学的にも明らかに $\beta$ 細胞の破壊を認めている，松 浦 $^{72}$ も鼠で同様のととを認め，乙の際甲状腺は $\mathrm{I}^{131}$ 摄取率，重量及び組織学的所見において機能克進状態を 認め, 又膵ラ氏島における $\beta$ 細胞の退行性変化並びそ減数を認めた。即ち TSH は糖尿病発症促進作用を有 し，その作用は主として甲状腺を介して行なわれることは疑えないとてろと考孚られる。私の TSH 投与実 験に於てみられた $\beta$ 細胞の機能充進も TSH の甲状腺を介しての糖代謝に及ぼす影響に伴う二次的なもの々 考えられ，てのような機能元進はやがて exhaution から機能低下への可能性を有するものと推定される. 従つててのような時期に $\beta$ cell tropic な alloxan 等を投与すれば reserve activity を失つた $\beta$ 細胞は容 易に障碍され糖尿病を惹起するであろうことは想像に難くない.

\section{c）成長ホルモン投与の影響}

家鬼に成長ホルモンを $10 \mathrm{mg} /$ head 52〜56日間継続投与しても血糖の上昇及び尿糖は認めなかつた。 その 時のラ氏島は $\beta$ 細胞よりの Insulin の放出が充進している像即ち $\beta$ 顆粒と亜鉛の減少が見られた。 又ラ氏 島面積も大となる傾向がみられた，核小体は変化がなく従つて Insulin 生成の充進と云うととは見るととが 出来なかつた。 $\alpha$ 細胞の核が稍々肥大を示していたがてれの意義は明らかでない．

一般に成長ホルモン投与により正常鬼，モルモット，ラットは糖尿病を起さないと云 $5^{73}$. 然し家鬼に於 て成長ホルモン $(\mathrm{GH}) \quad 1$ 日15〜30 mg投与によつて持続的に尿糖を証明しているものもある ${ }^{74}$. GH の催桾 尿病性については枚挙传腵がない程多くの報告があり, GH の $\beta$ 細胞に対する影響殊に $\beta$ 細胞促進作用 ${ }^{75 \sim 78)}$ 之抑制作用 ${ }^{79880)}$, 更には $\alpha$ 細胞の刺激作用 ${ }^{81 \sim 84}$ 並に GH の抗 Insulin 作用 $\left.{ }^{85 ~} 87\right)$ があげられる. 結局現在の ところ成長ホルモンの末梢組織における物質代謝に及ぼす影響により二次的に Insulin の分泌をうながし， その持続が $\beta$ 細胞の疲锶, 更には糖尿病に進展すると考えるのが妥当のようである. Anderson 等 ${ }^{88}$ もの剔 出膵の灌流によつて何らGHは Insulin の放出を促進しないととを報告している．私の得た家鬼における成 績では相当長期間に亘る投与にも拘らず僅が $\beta$ 細胞から Insulin の放出が促進していると解される程度の 所見であつた。乙れは動物の種属差と投与量の問題に㛿すべきものであろう.

\section{d）甲状腺剔出の影響}

ラット甲状腺剔出後 7 日のラ氏島では $\beta$ 細胞の収縮, 顆粒の極性の消失, 亜鉛の増量傾向等の所見よりす れば, Insulin の放出が低下しそのため貯蔵 Insulin が增加しているものと考学られる. 然し核及び核小体 飞変化の見られないところよりすれば Insulin の生成はそれ程低下していないものとみられる，甲状腺剔出 30日後となると，Insulin の放出の低下のみならず生合成の低下も起つてくるものと考学られ， $\beta$ 細胞の萎 縮， $\beta$ 顆粓及び西鉛，SS-SH 基の減少に加えるに $\beta$ 細胞核の明らかな縮小は之を物語るものである。乙の 場合 $\alpha$ 細胞にも核体績の減少がみられ，明らかに $\alpha$ 細胞の活性も低下しているものと思われる.

馬場 ${ }^{71}$ 亿よると糖尿病動物の甲状腺を摘出すると術前の Insulin 必要量の1/3で Insulin 痤攣を起す事が みられる。即ち糖原よりの糖転換及び肝糖放出作用と糖の腸管吸収之が甲状腺剔出によつて抑制され低血糖 準備状態となつているためと考えられる. 又 Walfson ${ }^{89}$ は犬の甲状腺を剔除しても血糖は低くならず勿論糖 尿も起らないととをたしかめたが，Britton and Meyers ${ }^{90)}$ は猫の用状腺を剔除するとInsulin 亿対する感受 性が著しく高まるのを見ている。即ち甲状腺剔出により Insulin の需要が低下し従つて Insulin 感受性も 相対的に高まるものと考皇られる，甲状腺剔出によるラ氏島の変化についての成績は比較的少ないが，Lorand $^{91)}$ は甲状腺を剔出すると島細胞が著明汇增殖するととを見ており，又前述の Eppinger ${ }^{64)}, M_{c}$ Callum ${ }^{65)}$ Friedman and Gottesman 等 ${ }^{66}$ は甲状腺と搭ではいずれかの腺を除去すると他方では機能充進の像がみられる とのべている，私の成績よりすれば甲状腺剔出による生体の代謝全体が低下するため Insulin 放出の必要が なくなり従つて $\beta$ 細胞の機能の静止状態が招来されるものと察せられる.

\section{e ）下垂体剔出の影響}

下垂体を剔出後 7 日目のラ氏自は $\alpha \cdot \beta$ 細胞共に細胞体と核は明らかな縮小を示し， $\beta$ 細胞では一部の細 胞に空胞形成がみられ顆粒は減少し亜鉛は反つて增加の傾向を示すてとは, Insulin 放出が低下し而も生成 
迄も相当程度抑制されているととを現わしているものと考えられる. 又 SS-SH 基反応の減弱も屡々見られ たがてれも生成の低下が代起りつつあるてとを示すものである。下垂体剔出15日目ではてれらの変化は一 層高度となり，业鉛も減少し核も濃縮に陣入るととはInsulin 生成が更に衰えたてとを示すものと考元てょ い. 下垂体剔出時の所見を甲状腺剔出時のそれと比較すると，後者は只単に代謝の低下に基づく Insulin 需 要の不足による Insulin 分泌の低下と更にそのために二次的に生合成も低下してくるものと考光られ，従 つてその程度も前者に比して軽度である，然し下垂体摘出時にははるかに強い機能の低下が $\alpha \cdot \beta$ 両細胞共 に起つて来る，乙れは上位内分泌腺たる下垂体の糖代謝に対する役割の大きいてとを物語るものであろう.

Ferner と Tonutti ${ }^{92)}$ はラット及びモルモットの下垂体を剔除すると著明な $\alpha$ 細胞の減少と菱縮性変化とが 緩漫に起き， 3 週後には一時的に元にもどり数ヶ月後には $\alpha$ 細胞の減少は再び著明となり一部の動物では $\alpha$ 細胞は完全に消失するが $\beta$ 細胞には著明な変化は見られないと述べている．Kracht ${ }^{93)}$ はやはり下垂体剔出ラ ットの $\alpha$ 及び $\beta$ 細胞の萎縮をみ， Mors $\mathrm{e}^{94}$ は下垂体剔出サルのラ氏島について $2 \cdot 3$ 例のものにラ氏島の数 と大きさが小となり， $\beta$ 細胞が幾分小さく $\beta$ 顆粒の軽度減少を報告している. Hultquist ${ }^{95)}$ は下垂体剔出後の $\alpha$ 細胞を計算し，7\%に減少しているのを認めている，てのように多くの報告は下垂体除去のラ氏島に及ほ す影響は $\alpha$ 細胞に強いとするもの， $\alpha \cdot \beta$ 両細胞に起るとするものが多い. 然し一方に於て Camber ${ }^{96)}$, Best ${ }^{97)}$ 及び Bryans $\left.{ }^{98}\right)$ 等は下垂体剔出イヌ及び成熟ラットに於て $\beta$ 細胞に組織学的変化を認めなかつたといつてい る.乙れらの成績は必ずしも種々の組織化学的方法及び計測とよつて一定の基準からなされたものでないた め報告者によつて discrepancy が起つてくるものと思われる. Marks and Yang ${ }^{99)}$, Houssay ${ }^{100101)}$ によれば 下垂体剔除動物を絶食にすると血糖值が漸時降下して遂に低血糖痙彎を起して死亡するがての際組織のグリ コーゲン量殊に肝グリコーゲンは減少している。このととは 1) 下垂体の抑制作用がとれて組織の糖質利用 が，肝の糖新生能力を越える，2）下垂体剔除は一次的に肝臟の糖新生速度を低下せしめ，末梢の利用速度 は正常でもこれに応じた糖量を供給出来なくなるからであるとしている，又 Fischer，Russell and Cori ${ }^{102}$ 及 び小島 ${ }^{67}$ は下垂体を剔除すると糖質の酸化又は利用が方進するとし，Krahl ${ }^{103)}$ ， Park ${ }^{104)}$ ， Stadie ${ }^{105)}$ によると 下垂体剔除によつて抑制がとれ增加した横隔膜の糖利用が Insulin の添加により更に刺激されることを報告 している. てれらの報告は何れも下垂体除去により動物は Insulin に sensitive となるととを示している. 私の成績もとの点より理解すべき二次的のものと解してよいと思われる.

\section{第 7 章 結 論}

下垂体甲状腺系の膵内分泌に対する影響について，ラット及び家鬼を用いて組織及び組織化学的に検討す ると共にラ氏島の形態と機能との関連についても検討し, 次の成績を得た。

1）甲状腺製剤 Thyradin は短期投与に於ては，ラ氏島 $\beta$ 細胞に対し機能充進的に作用し，Insulin 生産 が亢進しながらも唒貯蔵 Insulin の放出が之を上廻つている状態を認める．長期投与に於ては，上記機能立 進の長期継続による疲偪から $\beta$ 細胞の機能低下即ち Insulin の生産, 放出の低下から更に退行変性に至るも のと考える.

2) Pretiron (TSH) 投与は $\beta$ 細胞の機能進をうながすものと考えられ，短期投与では Insulin 生合成 の无進は認め得ないが Insulin 放出促進の状態が認められる．長期投与では $\beta$ 細胞においてその変化が著明 となり, Insulin の放出及び生合成の元進を示すものと考朰れる。乙のょうな $\beta$ 細胞の機能元進は TSH が甲状腺を介して糖代謝に及ぼす二次的影響と考える。

3） 家鬼に Growth hormone を長期間投与しても僅かに $\beta$ 細胞よりの Insulin 放出促進がみられる程度 で著明な変化は認められなかつた。

4) 甲状腺剔出により $\beta$ 細胞の機能の減弱を認める．乙れは甲状腺剔出による代謝低下に伴い Insulin 需 要が低下しこのため $\beta$ 細胞機能の静止状態が招来されるものと考える.

5）下垂体剔出により $\alpha \cdot \beta$ 細胞に退行性変化がみられ，機能の低下が認められる．即ち $\beta$ 細胞では Insulin の放出のみならず生合成の低下も起りつつあると考えられ，その程度は甲状腺剔出に比して遙かに高 
度である， $\alpha$ 細胞に於ける変化は $\beta$ 細胞に比し軽度であつた。

稿を終るに臨み，御眃篤なる御指導と御校閲を睗つた恩師吉田教授に厚く感謝の意を表すると共に，親し く御教示を頂いた教室の横尾助教授並びに青地博士に対し東心より謝意を表します。.

\section{附 図説 明}

第 1 図 正常ラット「ラ」氏島 CHP 染色 $700 \times$

$\alpha$ 細胞寡が $\beta$ 細胞を取り团むが如く存在ずる。 $\alpha$. $\beta$ 細胞共境界やや不明膫。 $\alpha$ 細胞原形質は phl一 oxin 飞強い染色性を示す。 $\beta$ 細胞原形質には hematoxylin 好性の顆粒が豊富に存在する。

第 2 図 正常ラット「ラ」氏島 aldehyde fuchsin 染色（以下A F 染色之略す） $700 \times$ 本質的には CHP 染色と同様所見であり， $\alpha$ 細胞原形質は橙色の微細顆粒が， $\beta$ 紐胞原形質には A F 亿よつて染わ出される微細顆粒が豊富に存在する。

第 3 図 Thyradin $20 \mathrm{mg} / 100 \mathrm{~g} 7$ 日間投与後のラット「ラ」氏島 CHP 染色 $700 \times$ $\beta$ 顆粒の軽度減少がみられる。

第 4 図 Thyradin $20 \mathrm{mg} / 100 \mathrm{~g} 30$ 日間投与後のラット「ラ」氏島 CHP 染色 $700 \times$ $\beta$ 細胞は顆粒減少, 水腫様変性, 核濃縮傾向が認められる。 $\alpha$ 細胞は phloxine 好性が稍々低下し ている。

第 5 図 TSH 10JSU/100g 30日間投与後のラット「ラ」氏島の CHP 染色 $700 \times$

$\alpha$ 細胞の比較的增殖がみられるが顆粒の変化は認められない。 $\beta$ 細胞は肥大，顆粒の脱失がみられ， 核染色質は微細となり分散して核は大きく明るくみえる。

第 6 図甲状腺剔出後 7 日のラット「ラ」氏島 CHP 染色 $700 \times$

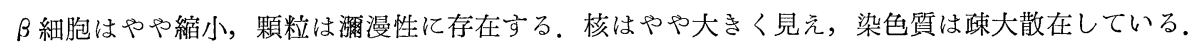
$\alpha$ 細胞は著変なし。

第 7 図 甲状腺剔出後 30 日のラット「ラ」氏島 CHP 染色 $700 \times$ $\beta$ 細胞は細胞質萎縮し，顆粒の減少がみられる。核は縮小している。 $\alpha$ 細胞には著変は認められな い.

第 8 図 下垂体剔出 7 日後のラット「ラ」氏島 A F 染色 $700 \times$ $\beta$ 細胞は縮小傾向を示し，顆粒はやや減少し辺縁化はみられない，核染色質は䠅大分散がみられる。 $\alpha$ 細胞は顆粒が減少している。

第 9 図 下垂体剔出 30 日後のラット「ラ」氏島 CHP 染色 $700 \times$ 上記変化が著明となり,一部 $\alpha$ 。 $\beta$ 細胞に空泡変性, 菱縮, 核濃縮がみとめられる.

第10図 正常家鬼「ラ」氏島 CHP 染色 $700 \times$ ラットそれと稍々異り， $\alpha$ 細胞は外套を作らず島周辺部に散在する一方島中心部にも散見される. $\alpha \cdot \beta$ 細胞共境界は比較的明膫。 $\alpha$ 細胞原形質は phloxine 飞強い染色性を示す。 $\beta$ 細胞原形質には $\mathrm{C}$ H好性の顆粒が充満し類洞腔側に強く認められる.

第11図 正常家免「ラ」氏島 A F 染色 $700 \times$ 本質的に CHP 染色と同㥞所見であるが，本染色では $\beta$ 顆粒の類洞腔に面して偏在の傾向が一層強 ?.

第12図 Thyradin 200mg/head 52〜56日間投与後の家貌「ラ」氏島 CHP 染色 $700 \times$

第13図 Thyradin 200mg/head 52〜56日間投与後の家鬼「ラ」氏島A F 染色 $700 \times$ 第12図，第13図共に同様所見がみられ， $\alpha$ 細胞は増殖し細胞体の肥大がみられる，顆粒は正常． $\beta$ 細胞数は減少し $\alpha$ 細胞にて圧排された観を呈する。 $\beta$ 細胞は縮小し顆粒は減少している.

第14図 成長ホルモン $10 \mathrm{mg} /$ head 52〜 56日間投与後の家巵「ラ」氏島A F 染色 $700 \times$ $\alpha$ 細胞は数がやや増加し，核の肥大がみられる。 $\beta$ 細胞では顆粒は正常又はややや減少し辺緑化が 第 40 巻 第 7 号 
著明となる。

第15図 正常ラット「ラ」氏島亜鉛染色 $700 \times$

$\beta$ 細胞には微細な好銀性顆粒が原形質辺縁部に密集して存在する。 $\alpha$ 細胞には $\beta$ 細胞より一層高い 密度の顆粒の存在をみる。

第16図 Thyradin $20 \mathrm{mg} / 100 \mathrm{~g} 7$ 日間投与後のラット「ラ」氏島亜鉛染色 $700 \times$ $\alpha$ 細胞では黒色の好銀性物質はやや減少傾向がみられる。 $\beta$ 細胞は変化なし.

第17図 Thyradin $20 \mathrm{mg} / 100 \mathrm{~g} 30$ 日間投与後のラット「ラ」氏覀鉛染色 $700 \times$ $\alpha \beta$ 細胞共とくに $\beta$ 細胞に扔いて好銀性物質は著明に減少している.

第18図 TSH 10JSU/100g 7 日間投与後のラット「ラ」氏島亜鉛染色 $700 \times$ $\beta$ 細胞では好銀性物質は極く微弱陽性， $\alpha$ 細胞には猶相当量の顆粒が存在する.

第19図 TSH 10JSU/100g 30日間投与後のラット「ラ」氏島亜鉛染色 $700 \times$ $\beta$ 細胞では黒色沈着物は消失し， $\alpha$ 細胞と思われるところに僅に黒色沈着物をみる.

第20図甲状腺剔出 7 日後のラット「ラ」氏島亜鉛染色 $700 \times$ $\alpha$ 細胞は変化なく， $\beta$ 細胞に於ては正常と同程度乃至それ以上の沈着物を認める。

第21図甲状腺剔出後 30 日のラット「ラ」氏島亜鉛染色 $700 \times$ $\alpha$ 細胞では相当量の沈着物を認めるが， $\beta$ 細胞では著明な亜鉛の減少をみる。

第22図 下垂体剔出後30日のラット「ラ」氏島亜鉛染色 $700 \times$ 好銀性物質は両細胞共にやや減少を認める程度であるが，対照に比しその存在は極性を示さず，細 胞体内に均等に存在する。.

第23図正常家鬼「ラ」氏亜鉛染色 $1000 \times$ 家躳では好銀性物質は $\beta$ 細胞のみにみられ， $\alpha$ 細胞には殆んど全く認められない， $\beta$ 細胞では核周 辺部は蹯に，辺縁部では濃密な顆粒状物質がみとめられる.

第24図 Thyradin 200mg/head 52～56日間投与後の家鬼「ラ」氏島亜鉛染色 $800 \times$ $\beta$ 細胞では明らかに亜鉛の減少が認められる,

\section{文献}

1) HOUSSAY, B.A. : Endocrinology, $35:$ 158, (1944). $\quad$ 2) HOUSSAY, B.A.: Rec. Prog. Hor. Res., 2 : 277, (1948). 3) HOUSSAY, B.A. and ANDERSON, E. : Endocrinology, $45: 627,(1949)$. 4) CAMPBELL, J. et al. : Endocrinology, $46: 588,(1950) . \quad$ 5) GOLDNER, M.G. and B.W. VOLK : Ciba Foundation Colloq. on Endocrinology, $9: 75,(1957)$ 6) LEHEY : quoted by Joslin et al : Treatment of Diabetes Mellitus, Lea \& Febiger, Phila., p.625, (1952). 7) DALTON, A.J. : Amer. J. Anat., 89 : 109, (1951). $\quad$ 8) ROBERTSON, J.S. : Australian J. exp. Biol. med. Sc., $32: 229$, (1954). $\quad$ 9) LAGY, P.E. : Anat. Rec., $128: 225$, (1957). 10) LACY, P.E. : Diabetes, $6:$ 498, (1957). 11) GOMORI, G. : Anat. Rec., $74: 439$ (1939). 12) LAQUSSE, E. : J. Anat. Physiol., London, $30: 591$, (1894). 13) GOMORI G. : Amer. J. Clin. Path., 20 : 665, 1950. 14) BELL, E.T. : Diabetes, $2: 125$, (1953). 15) HARTROFT, W.S. and WRENSCHALL, G.A. : Diabetes, $4: 1,(1955)$. 16) WRENSCHALL, G.A. et. al. : Diabetes, $3: 444,(1954)$. 17) PFEIFFER, E.F., W. SANDRITTER, U. BECKER und D. MÜLLER : Endokrinologie, 37 : 193 , (1959). 18) 吉田秀雄他：日本内分泌誌，34:758，(1958)。19) 吉田秀雄他：日本内分泌誌, 34 : 82, (1958). 20) LAZARUS, S.S. and BARDEN, H. : J. Histchem. \& Gytochem., $9: 628,(1961)$. 21) LAZARUS, S.S. and VOLK, B. : The Pancreas in Human and experimental Diabetes, New York, Grune \& Straton, P. 55, (1962). 22) OKAMOTO, K. : Trans. Soc. Path. Jap., 33 : 99, (1942). 23) WOLFF, H.P. et al. : Z. ges. exp. Med., $126: 390$, (1955).

24) MONIKE, G., V. MORITZ 
und H.G. LIPPMAN : Endkrinologie, $45: 67,(1963)$.

25) PETERSON, $\mathrm{K}$ and J. SCHLIGHTKRÜLL : Science, $116: 394, \quad(1952)$.

26) BARRNETT, R. J. et al. : Endocrinology, $57: 419$, (1955). 27) BARRNETT, R.J. and SELIGMAN, A.M. : Science, $116: 323,(1952)$ 28) BARRNETT, R.J. et al. : J. Nat. Cancer Inst., 14 : 769, (1954). 29) LAZAROW, A. : Diabetes, 6 : 222, (1957). 30) BAHR, G.F. : Acta radiol., Stockholm. suppl., 147,(1957). 31) GÖSSNER, W. : Histochemie, $1: 48,(1958)$. 32$)$ DEMPSY, E.W., R.O. GREEP and H.W. DEANE : Endocrinology, $44: 88$, (1949).

33) CASPERSON, T.O. : Gell Growth and Cell Function, New York (1950) W.W. Norton Company.

34) HULTQUisT, G.T. und B. THORELL : Acta Path. Microbiol. Scand., 32 : 245, (1953).

35) FITZGERALD, P.J. : Ann. N.Y. Acad. Sci., $63: 1141$, (1956). 36) HAIST, R.E. and E.J. PUGH : Am. J. Physiol., 152 : 36,(1948). 37) BEST, G.H., J. Campell, R.E. HAIST and A.W. HARN : J. Physiol., 101: 17, (1942).

38) BENSLEY, R.R. : Amer. J. Anat., 12 : 297,(1911/12).

39) JEJNING, St. : Acta medica Scand. Suppl., 198, (1947). 40) OGILVIE, R.E. : J. Path. Bact., 37 : 473, (1933). 41) OGILVIE, R.E. : Quart. J. Med., $28: 345$, (1935) and $30: 287,(1937)$ 42) FERNER, H.:Virchows Arch. Path. Anat., 309: 87, (1942). 43) FERNER, H. : Das Inselsystem des Pancreas, Stuttgart, (1952). 44) HESS, W. : Schweiz. Zshr. Path., $9: 46,(1945) . \quad 45)$ GREUZFELDT, W. : Beitr. Path. Anat., 113 : 133, (1953). 46) GREUZFELDT, W. : Wien Zschr. inn. Med., $37: 217,(1956)$. 47) SEIFERT, G.: Virchows Arch. Path. Anat., $325:$ 379, (1954). 48) BAKEY : Pflügers Arch. Physiol., 243 : 733 , (1940). 49) GÜTHERT, H. : Virchows Arch. Path. Anat., $307: 175,(1941) . \quad 50)$ KRACHT, J. : Endokrinologie, $36: 146,(1958)$ 51) KRACHT, J. : Naturwiss., $40: 607,(1953), 41: 336,(1954)$, $42: 50$, (1955), $43: 18$, (1956). 52) KRACHT, J. und M. SPAETHE : Zschr. wiss. Mikrosk., $62: 227,(1955)$ 53) HOLT, C., J. KRACHT, B. KRÖNER und L.V. HOLT : Schweiz. med. Wschr., (1956) : $1123 . \quad 54)$ J. KRACHT $:$ Endokrinologie, $37: 4,(1959) . \quad 55)$ JOACHIM, KRACHT : Endokrinologie, $36: 146$, (1958). 56) MONIKE, G. et al. : Endocrinology , 45 : 59, (1963)。57) 室根郁男：日本内分泌誌，35：442,(1959)。 58) 桑田美智子他：日本内分泌誌，35： 909, (1960)。 59) 横尾定美：内本内分泌誌，38:572, (1962)。 60) JOSLIN : quoted by Joslin et al : The Treatment of Diabetes Mellitus, Lea \& Febiger, Phila., p. 625,(1952.) 61) REGAN: Arch. Int. Med., $65: 1116,(1940)$. 62) ROOT : quoted by Joslin et al. : The Treatment of Diabetes Mellitus, Lea \& Febiger, Phila., p. 625, (1952)。 63) 藤田輝雄 : 日本内分泌誌, $38: 565$, (1962). 64) EPPINGER, H. et al. : die Zentralb. f. Klin. Med., $66: 1,(1908)$. 65) McGALLUM, W.G. : Bull. Jahns Hopkins Hosp., 20 : 265,(1909). 66) FRIEDMAN, G.A. and· J. GOTTESMAN : Proc. Soc. exper. Biol. Med., 19 : 209〜225, (1921)。 67) 小島正守 : 日本内分泌誌, 36: 1858, (1961). 68) HORSTERS,H. : Arch. exp. Path. Pharmak., $169: 537,(1933)$ 69) ZUNZ, E. et J. La BERRE, C.R. : Soc. Biol., Paris, 118,(1174). 70) 富田明夫 : 日本内分泌誌, 35 : 1153, (1960). 71) 馬場茂明他：日本内分泌䓌，34:1209, (1959)。72) 松浦昭三 : 日本内分泌誌， $32: 748$, (1956). 73) ABELOVE, W. and K.E. PASCHKIS : Endcrinology, 55 : 637,(1954.) 74) OGILVIE, R.E., N. MACLEAN : Ch. B. Edinburgh, Diabetes, $9: 38,1960.7$ 75) MILMAN, A. E., J.A. RUSSEL : Endocrinology, $47: 114,(1950)$. 76) SCOTT, Jr. J. and F.L. ENGEL : Endocrinology, $46: 582,(1950)$ 77) KURZ, M. et al. : Proc. Soc. exp. Biol., $76: 21(1951)$ 78) PARK, C.R. et al. : J. biol. Chem., $197: 151,(1952)$. 79) ANDERSON, E., J.A. LONG : Endocrinology, $40: 98,(1947)$ 80) LOTSPEICH, W.D. : J. Biol. Chem., $185: 221$, (1950). 81) FERVER, H. : Klin. Wschr., $1: 397,(1951)$ 82) BORNSTEIN, J. et al. : Nature, 168 : 908, (1951). 83) FOA, P.P. et al. : Proc. Soc. exp. Biol., 83 : 758,(1953). 14) MAYER, J., SILIDES, D.N. : 
Endocrinol., $52: 54,(1953)$.

85) DeBODO, R.G. et al. : Fd. Proc, $8: 32,(1949)$.

MILMAN, A.E., J.A. RUSSEL : Endocrinol., 47 : 114, (1950).

87) GAMPBELL, J. et al. : Endocrinol., 53 : 135, (1953). 88) ANDERSON, E. and BATES, R.W. : Fed. Proc., $18: 4$, (1959). $\quad$ 89) WOLFSON, H. : Amer. J. Physiol., 81 : 453, (1927).

90) BRITTON, S.W. and W.K. MEYERS : Amer. J. Physiol., 84 : 132,(1927).

91) LORAND, A. : G.r. Soc. Biol., 56 : 488, (1913).

92) FERNER, H. und E. TONUTTI : Z. Zellforsch., 38 : 267, (1953).

93) KRACHT, J. : Naturwissenschaften, $40: 607,(1953)$. 94) MORSE, A. et al. : Anat. Rec., 127 : 338, (1957). $\quad$ 95) HULTQUIST, G. et al. : Schweiz. Z. all. Path., $11: 570$, (1948).

96) GAMBER, S. and CHANDLER : Am. J. Physiol., $113: 26,(1935) . \quad 97)$ BEST, G.H. et al. : J. Physiol., $101: 17,(1942) . \quad$ 98) BRYANS, F.E. et al. : Diabetes, $1: 358$, (1952). 99) MARKS, H.P. and YANG, F.G. : Lancet, $1: 493$, (1940). 100) HOURSAY, B.A.: Ann. Rev. Physiol., 5 : 373, (1943). 101) RUSSEL, J. A. : Essays in biology,p. 305, Berkelev University of California Press, (1944). 102) FISCHER, R.E., RUSSEL, J.A. and C.F. CORI : Biol. Chem., $115:$ 627, (1936). 103) KRAHL, M.E. and G.R. PARK : J. Biol. Ghem.,174 : 939, (19 48). 104) PARK, C.R. and W.H. DANGHADAY : Fed. Proc., $9: 212$, (1950). 105) STADIE, W.C., HANGAAD, N. and MARSH, J.B. : J. Biol. Chem., 188 : 167, (1951). 


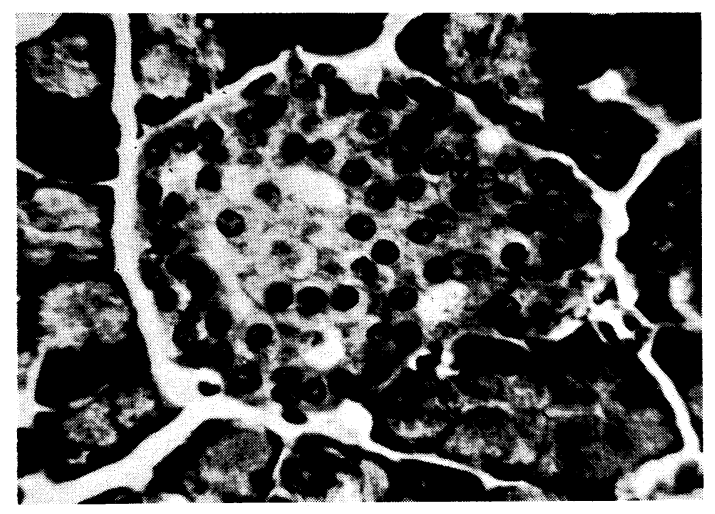

第 1 図

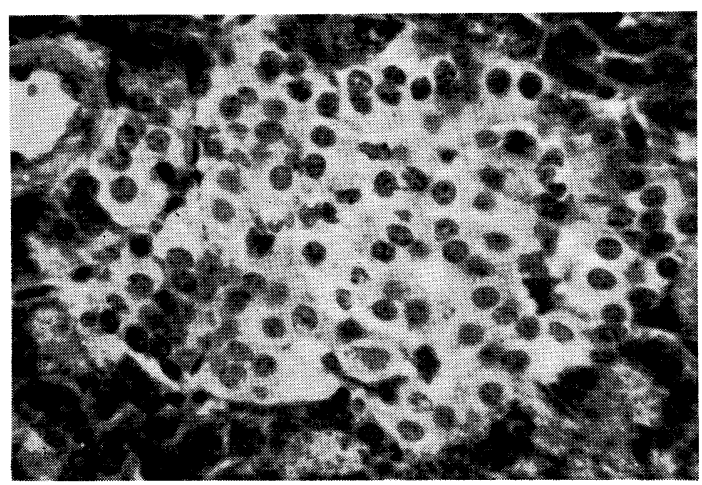

第 3 睬

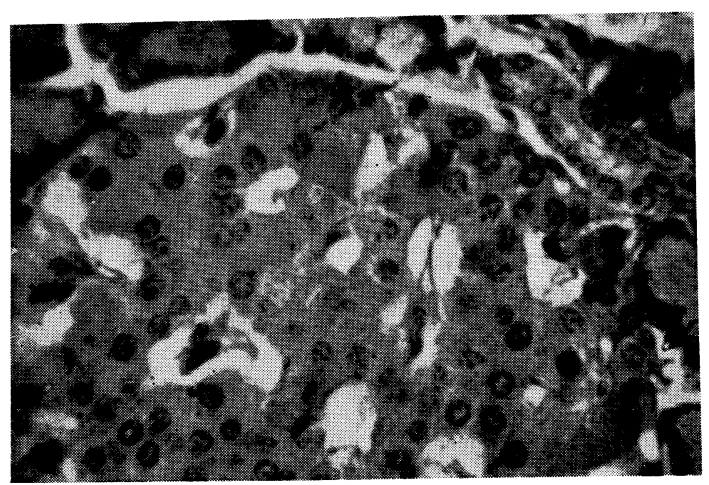

第 5 図

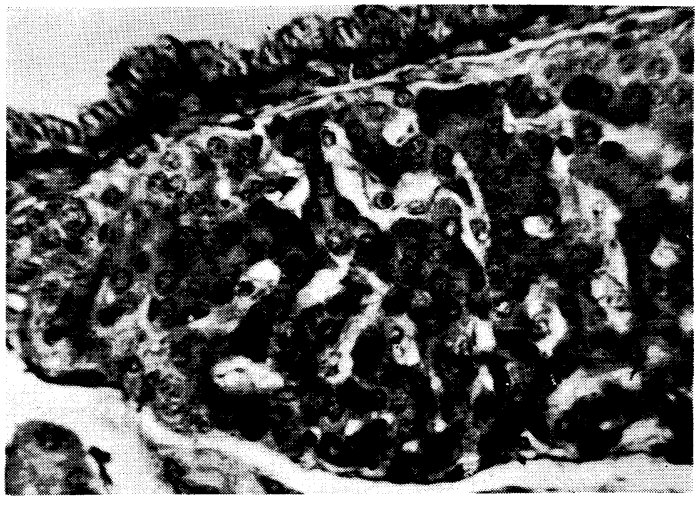

第 2 図

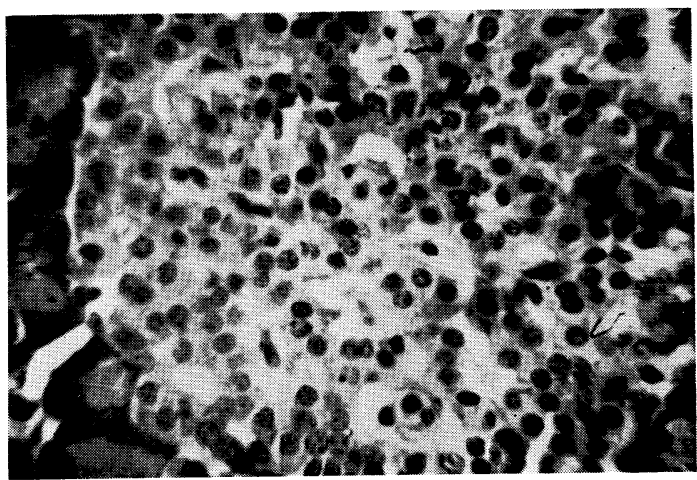

第 4 図

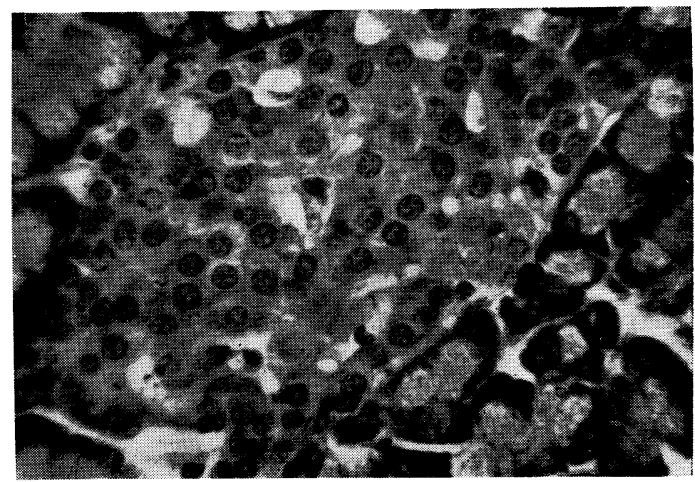

第 6 図 


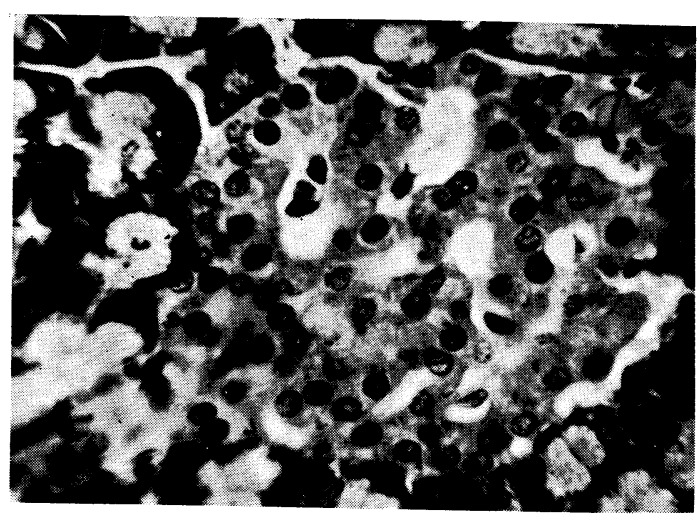

第 7 図

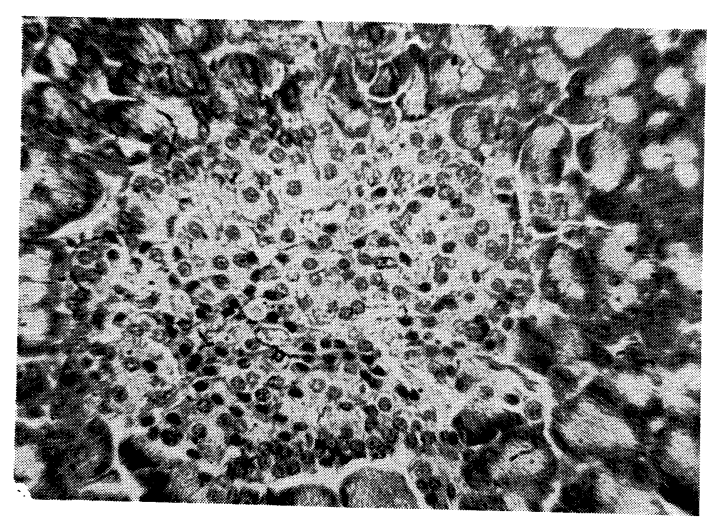

第 9 図

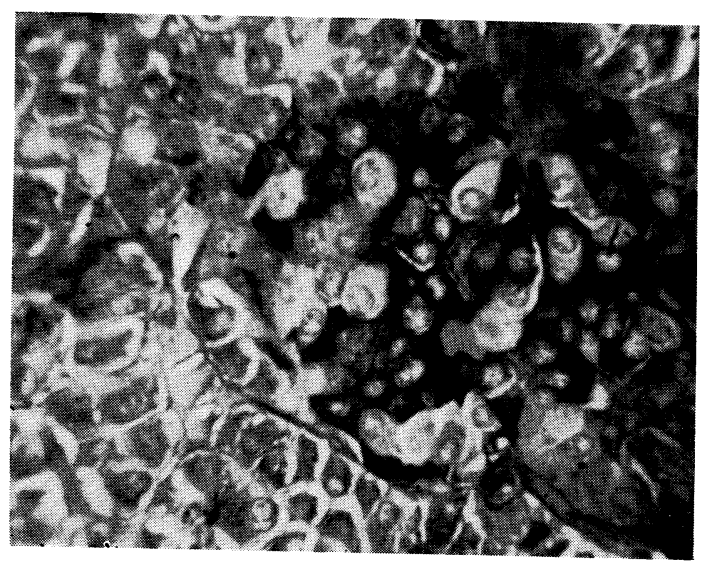

第 11 図

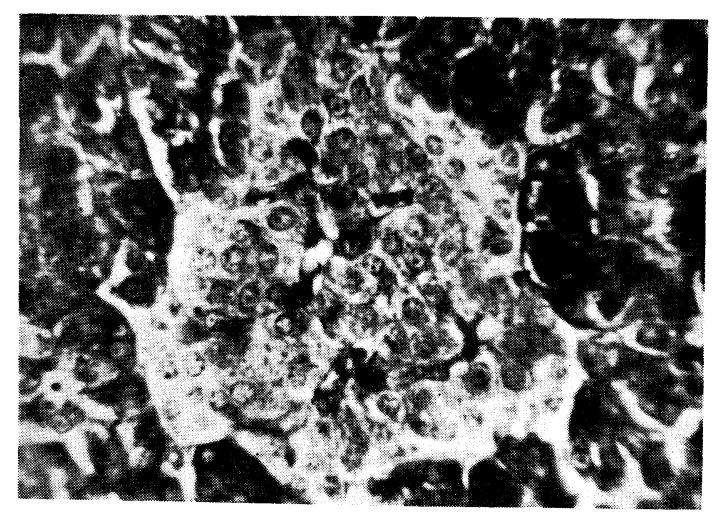

第 8 図

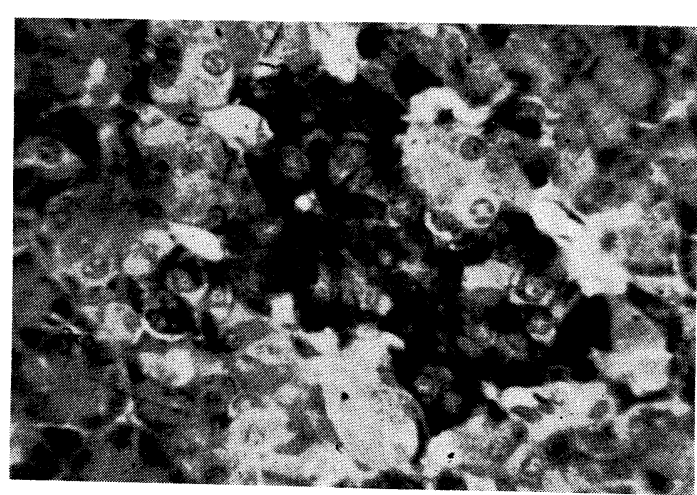

第 10 図

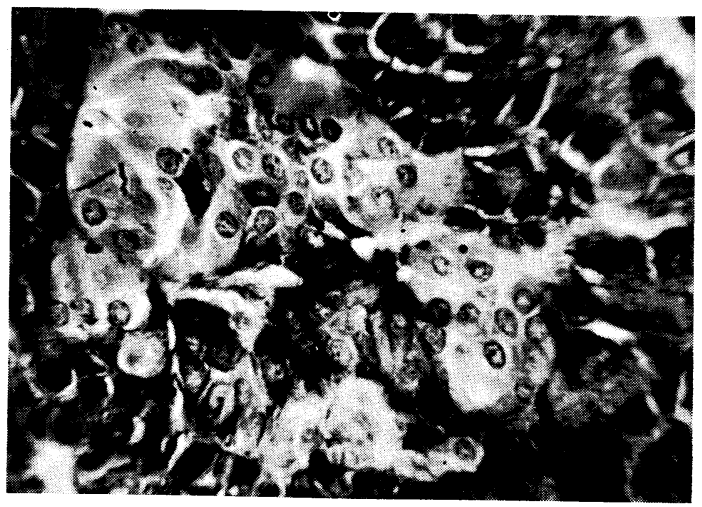

第 12 図 


\section{正木論文附図（その 3 )}

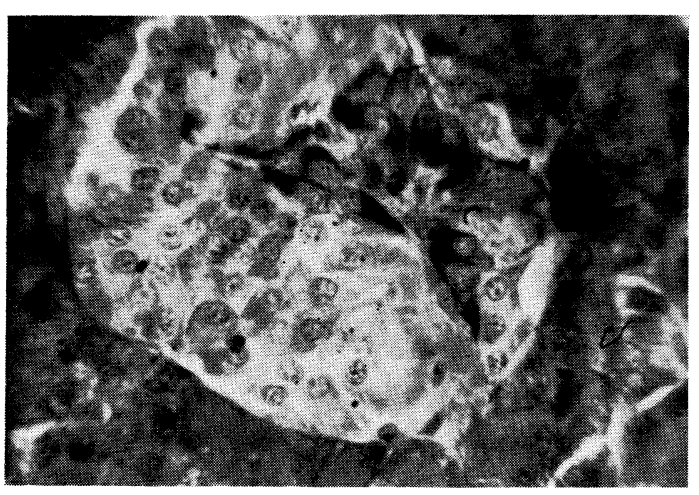

第 13 図

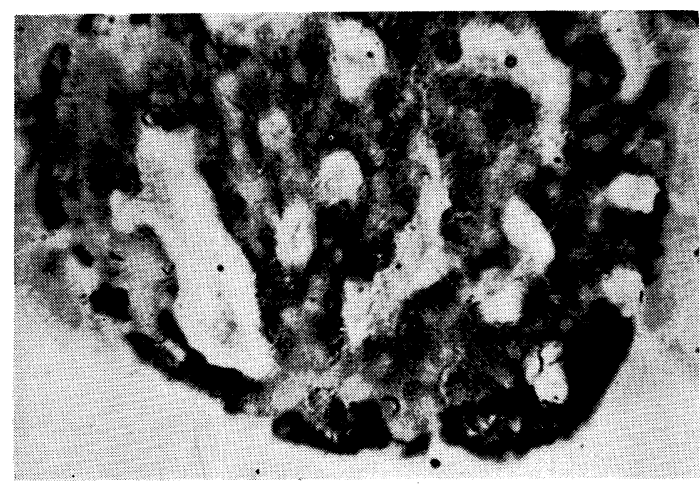

第 15 図

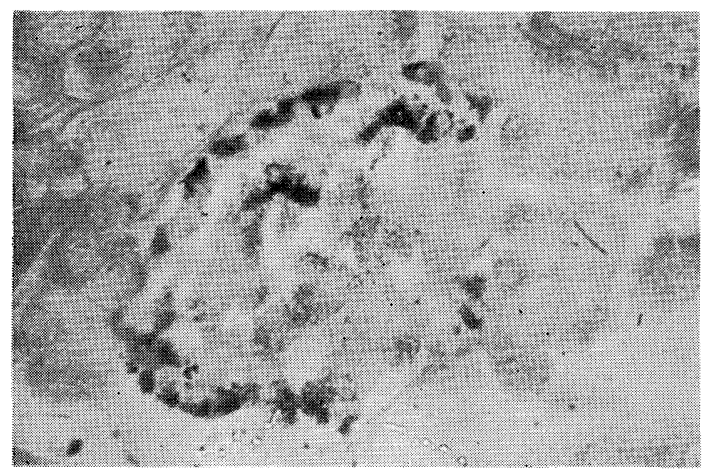

第 17 図

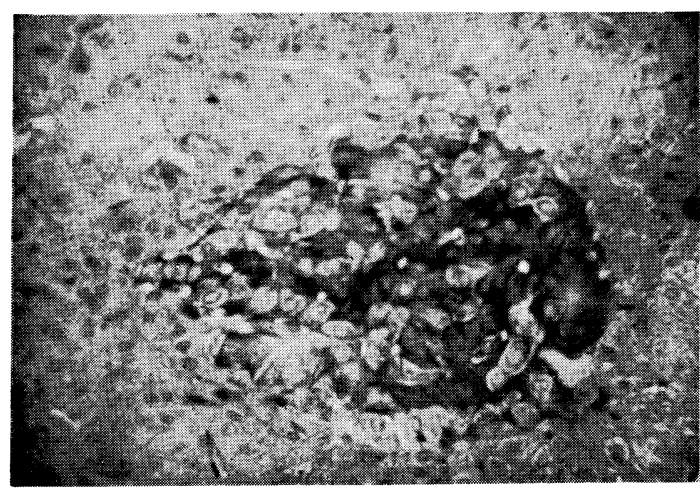

第 14 図

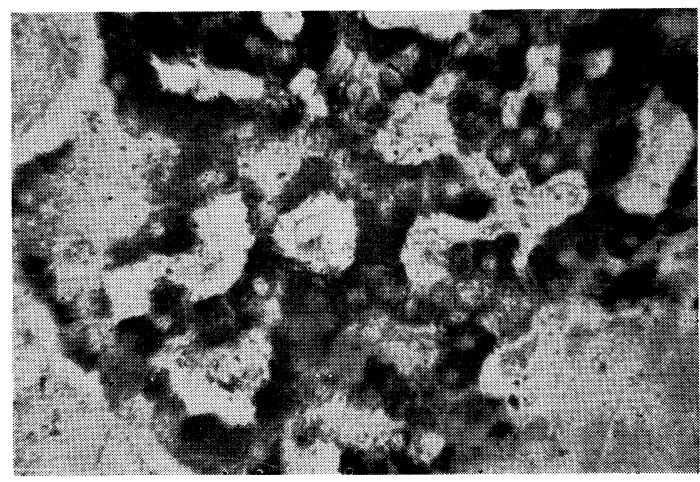

第 16 図

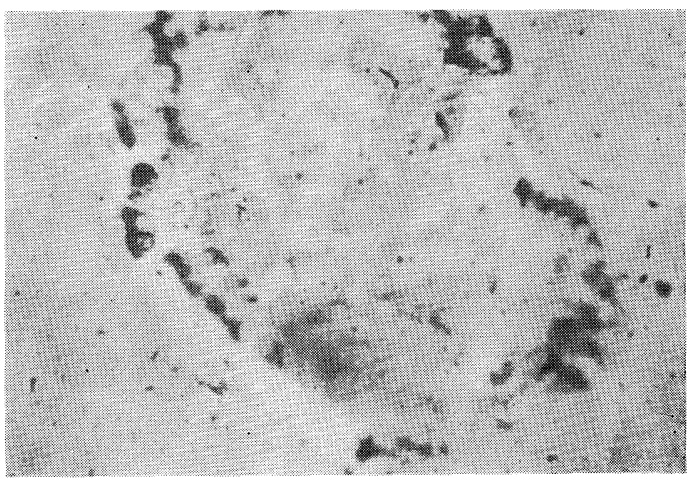

第 18 図 


\section{正木論文附図（その4)}

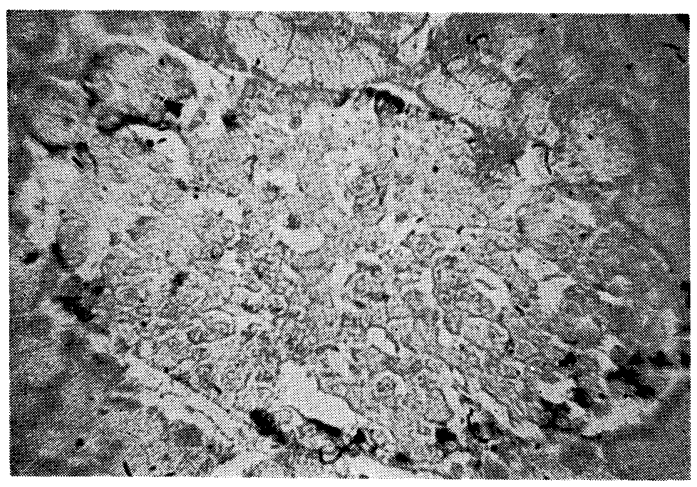

第 19 図

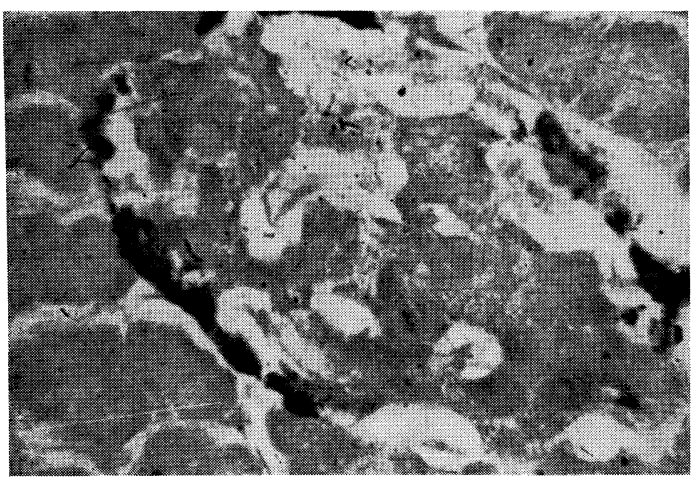

第 21 図

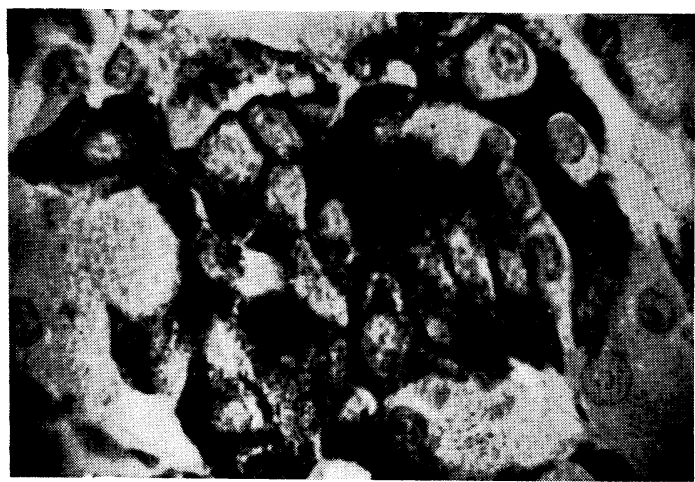

第 23 図

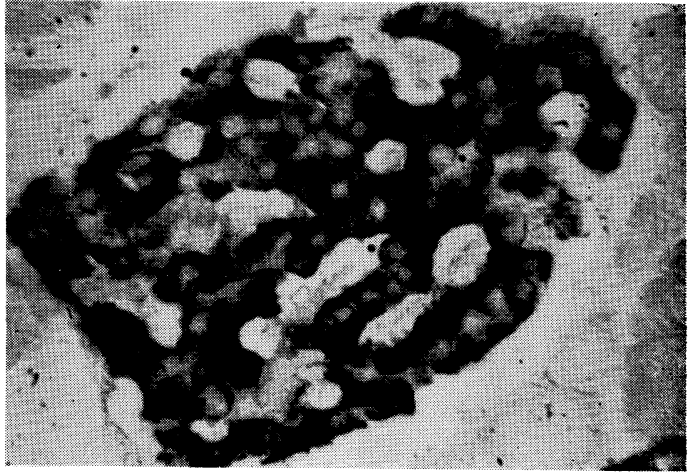

第 20 図

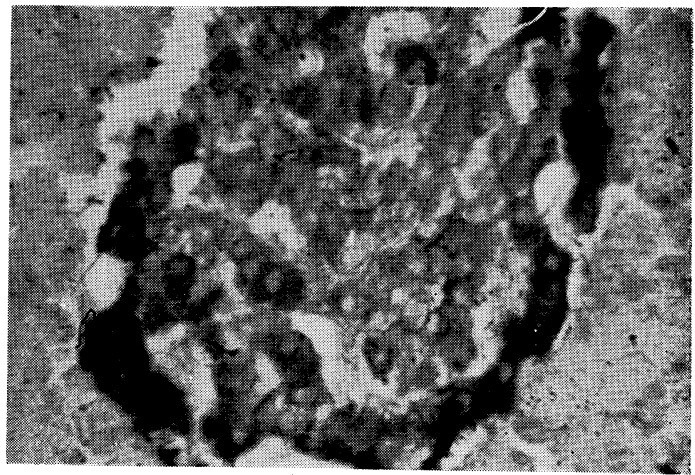

第 22 図

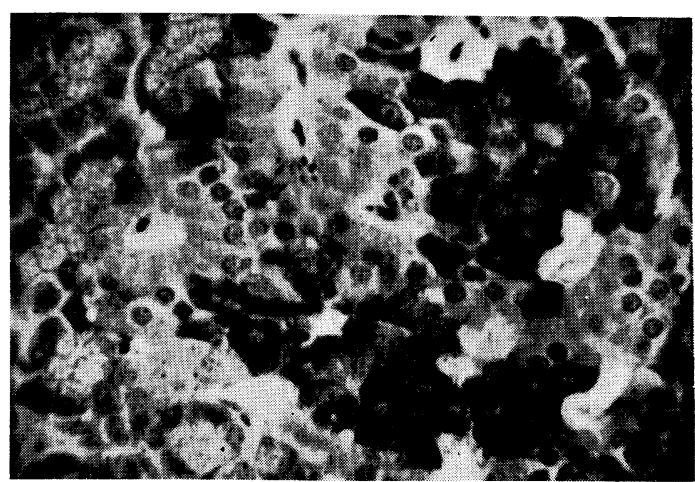

第 24 図 